\title{
Regulation of intraocular pressure by soluble and membrane guanylate cyclases and their role in glaucoma
}

\author{
Emmanuel S. Buys ${ }^{1 *}$, Lincoln R. Potter ${ }^{2}$, Louis R. Pasquale ${ }^{3}$ and Bruce R. Ksander ${ }^{4}$ \\ Department of Anesthesia, Critical Care, and Pain Medicine, Anesthesia Center for Critical Care Research, Harvard Medical School, Massachusetts General \\ Hospital, Boston, MA, USA \\ ${ }^{2}$ Department of Pharmacology, University of Minnesota Medical School, Minneapolis, MN, USA \\ ${ }^{3}$ Department of Ophthalmology, Glaucoma Service Mass Eye and Ear Infirmary and Channing Division of Network Medicine, Harvard Medical School, Brigham and \\ Women's Hospital, Boston, MA, USA \\ ${ }^{4}$ Department of Ophthalmology, Massachusetts Eye and Ear Infirmary, Schepens Eye Research Institute, Harvard Medical School, Boston, MA, USA
}

\section{Edited by:}

Clint Lawrence Makino, Harvard Medical School, USA

Reviewed by:

Bin-Nan Wu, Kaohsiung Medical University, Taiwan

Alan Marmorstein, Mayo Clinic, USA

${ }^{*}$ Correspondence:

Emmanuel S. Buys, Department of Anesthesia, Critical Care, and Pain Medicine, Anesthesia Center for Critical Care Research, Harvard Medical School, Massachusetts General Hospital, 55 Fruit Street, Thier 511B, Boston, MA 02114, USA e-mail: ebuys@mgh.harvard.edu
Glaucoma is a progressive optic neuropathy characterized by visual field defects that ultimately lead to irreversible blindness (Alward, 2000; Anderson et al., 2006). By the year 2020, an estimated 80 million people will have glaucoma, 11 million of which will be bilaterally blind. Primary open-angle glaucoma (POAG) is the most common type of glaucoma. Elevated intraocular pressure (IOP) is currently the only risk factor amenable to treatment. How IOP is regulated and can be modulated remains a topic of active investigation. Available therapies, mostly geared toward lowering IOP, offer incomplete protection, and POAG often goes undetected until irreparable damage has been done, highlighting the need for novel therapeutic approaches, drug targets, and biomarkers (Heijl et al., 2002; Quigley, 2011). In this review, the role of soluble (nitric oxide (NO)-activated) and membrane-bound, natriuretic peptide (NP)-activated guanylate cyclases that generate the secondary signaling molecule cyclic guanosine monophosphate (cGMP) in the regulation of IOP and in the pathophysiology of POAG will be discussed.

Keywords: guanylate cyclase, nitric oxide, natriuretic peptides, glaucoma, open-angle, intraocular pressure

\section{PRIMARY OPEN ANGLE GLAUCOMA}

Primary open-angle glaucoma (POAG) is a leading cause of blindness, affecting over 2.2 million patients in the US alone, and is associated with an estimated health care cost upwards of $\$ 1.5$ billion/year. Vision loss, occurring due to loss of retinal ganglion cells (RGCs) and degeneration of the optic nerve, has far-reaching effects on the patient's ability to function independently, dramatically affecting quality of life from a physical, mental and social well-being perspective. Currently, there is no definitive cure for POAG and although multiple risk factors for POAG have been identified [including intra-ocular pressure (IOP), race, age, and genetic factors], the molecular signaling involved in POAG pathogenesis remains largely unknown.

Although multiple POAG risk factors have been identified, the etiology of POAG remains to be elucidated, likely because the disease can be stratified into various subtypes defined by discrete but yet unknown biochemical pathways. Two major pathophysiologic mechanisms for POAG have been proposed. In the "mechanical theory" optic neuropathy is caused by increased IOP (see "Intraocular pressure: a risk factor for POAG" below). Alternatively, a vascular component has been hypothesized to contribute to POAG pathophysiology (see "Glaucoma and vascular dysfunction" below). However, the extent to which vascular dysfunction contributes to glaucomatous optic neuropathy remains to be elucidated and is controversial (Vajaranant and Pasquale, 2012).

\section{INTRAOCULAR PRESSURE: A RISK FACTOR FOR POAG}

POAG is often associated with elevated IOP. Measurement of IOP typically requires an anesthetized ocular surface and a cooperative patient, as corneal applanation is needed for accurate measurement of this ophthalmic vital sign. While POAG is a strongly age related disease (Sommer et al., 1991; Mukesh et al., 2002) and elevated IOP is a major risk factor for this condition, IOP does not necessarily increase with age. One longitudinal analysis found that among people aged 50-59, IOP increased after 9 years of follow-up but among subjects 60 and older, a slight decrease in IOP was noted in the same time period (Wu et al., 2006). Furthermore while African heritage is an undisputed risk factor for POAG, people of African heritage do not necessarily have higher IOP than Caucasian subjects drawn from the same population (Sommer et al., 1991). While the heritability of IOP is relative highly (56-64\%) (Carbonaro et al., 2009) very few common loci for this trait have been discovered thus far (Van Koolwijk et al., 2012; Ozel et al., 2014). Other factors such as body mass index (Klein et al., 1992; Wu and Leske, 1997; Oh et al., 2005), blood pressure (Klein et al., 2005), and diabetes (Wu et al., 2006) have only modest positive associations with IOP. Data regarding how IOP might change while blood pressure varies in an individual patient are lacking. When a patient (regardless of glaucoma status) transitions between a seated to supine position there is a predictable increase in IOP of $\sim 3 \mathrm{~mm}$ $\mathrm{Hg}$ (Lee et al., 2012, 2013). Only a few medical conditions impact the level of IOP (Arevalo et al., 1996; Garcia Filho et al., 2011) but steroid exposure is notorious for leading to elevated IOP via 
changes in trabecular meshwork permeability (Clark et al., 1995). It is thought that IOP fluctuates more in POAG patients than controls (Sacca et al., 1998) but the literature is conflicting regarding the role of IOP fluctuation on open-angle glaucoma disease progression (Nouri-Mahdavi et al., 2004; Bengtsson et al., 2007).

IOP is determined by the balance between the production/secretion of aqueous humor $(\mathrm{AqH})$ by the ciliary processes and by the drainage of $\mathrm{AqH}$ via the iridocorneal angle. $\mathrm{AqH}$ can exit the eye through various routes: the conventional, the uveoscleral, and the uveolymphatic pathways. The conventional pathway consists of the trabecular meshwork (TM), Schlemm's canal, collecting channels, and the episcleral venous system. It is generally accepted that IOP reflects the pressure necessary to overcome the intrinsic resistance to aqueous outflow that occurs at the junction where the juxtacanalicular part of the TM meets the inner wall of Schlemm's canal (Ethier et al., 1986). In uveoscleral outflow, $\mathrm{AqH}$ drains through the ciliary muscle (CM) and exits through the supraciliary space and across the anterior or posterior sclera, into choroidal vessels (Fautsch and Johnson, 2006). Uveoscleral outflow, accounting for anywhere between $3 \%$ and $80 \%$ of outflow depending on the species studied (4-60\% in humans) (Fautsch and Johnson, 2006), is particularly impacted by age, an important observation considering the age-dependency of POAG in both patients (Kass et al., 2002, 2010; Mukesh et al., 2002; De Voogd et al., 2005; Rudnicka et al., 2006; Leske et al., 2008) and animal models (Buys et al., 2013). Incidentally, also in animal models of secondary angle-closure glaucoma, IOP and prevalence of optic neuropathy and retinal lesions increased with age (John et al., 1998; Saleh et al., 2007). More recently, the existence of a third outflow route was postulated: lymphatic channels in the stroma of the ciliary body and interstitial spaces between CM muscle bundles may function as a backup outflow system (Yucel et al., 2009). The relevance of this uveolymphatic pathway and whether NO-cGMP signaling (see "NO-cGMP signaling in the eye" below) modulates contractility of ocular lymphatic vessels remains to be determined. Importantly, a central role for NO in lymphatic function was recently identified (Liao et al., 2011). Whether the effect of $\mathrm{NO}$ on lymphatic contractions is mediated by cGMP remains unknown.

In contrast to what is observed in angle closure glaucoma, POAG is not associated with apparent blockage of the anterior chamber angle. In POAG, there is variable elevation of IOP associated with impaired $\mathrm{AqH}$ outflow that occurs despite apparently normal anterior segment anatomy and an open iridocorneal angle (Weinreb and Khaw, 2004). IOP rises gradually over time, likely as a consequence of decreased drainage of AqH. IOP-lowering treatment significantly cuts the risk of developing glaucoma in ocular hypertensives (Kass et al., 2002, 2010).

\section{GLAUCOMA AND VASCULAR DYSFUNCTION}

While IOP reduction continues to be a successful treatment to reduce the progression of POAG (Leske et al., 2003; Kass et al., 2010), the pathogenesis of POAG seemingly also depends on factors other than increased IOP. Compounds that do not lower IOP dramatically may have properties that address the underlying glaucomatous disease process and therefore could be suitable therapeutic agents (Weinreb and Kaufman, 2009; Chen et al.,
2011). For example, brimonidine was superior to timolol in stabilizing visual field deterioration, despite producing a similar IOP-lowering effect (Krupin et al., 2011). Also, ocular hypertension does not necessarily lead to POAG and ocular normotension does not preclude the development of POAG (Leske et al., 2001), suggesting that other pathologies, including neurologic (similar to other chronic central nervous system diseases such as Alzheimer's diseases or Multiple Sclerosis Quigley, 2011) or vascular dysfunction [e.g., as characterized by impaired retinovascular autoregulation (Feke and Pasquale, 2008) or peripheral vascular endothelial dysfunction (Henry et al., 1999; Su et al., 2008)], may contribute to the etiology of POAG. Vascular dysfunction contributes to the development of systemic hypertension (Mendelsohn, 2005; Michael et al., 2008) and several studies have provided evidence that blood pressure affects POAG risk (Kaiser and Flammer, 1991; Tielsch et al., 1995; Hulsman et al., 2007; Leske et al., 2008; Memarzadeh et al., 2010; Cherecheanu et al., 2013). In addition, the idea that vascular dysfunction contributes to the pathogenesis of POAG is based on the hypothesis that decreased perfusion of the optic nerve leads to neurodegeneration (Harris et al., 2005; Vajaranant and Pasquale, 2012).

Both impaired blood flow and impaired vascular autoregulation have been described in glaucoma patients (Flammer et al., 2002; Feke and Pasquale, 2008; Moore et al., 2008; Feke et al., 2011). Large epidemiologic studies have found adverse associations between POAG and low ocular perfusion pressure (OPP) (Hulsman et al., 2007; Leske, 2009) or low systemic blood pressure (Bonomi et al., 2000). In addition, the Early Manifest Glaucoma Trial observed that predictors of POAG disease progression included lower systolic blood and perfusion pressure (Leske et al., 2007). Especially in normal tension glaucoma patients, systemic vascular abnormalities have been described, including impaired flow- or acetylcholine-mediated vasodilation (Gasser and Flammer, 1991; Henry et al., 1999; Su et al., 2008). Also POAG patients with early paracentral visual field loss are more likely to have systemic vascular risk factors such as hypotension and migraines (Park et al., 2011, 2012). It is important to note that blood flow regulation in the optic nerve head seems to be strongly dependent on IOP and OPP (Schmidl et al., 2011). The interaction between systemic blood pressure and IOP (defining OPP) (Tielsch et al., 1995; He et al., 2011) is particularly relevant for this review, given the role of NO-cGMP signaling (see "NO-cGMP signaling in the eye" below) in both the regulation of IOP and systemic blood pressure.

\section{NO-cGMP SIGNALING IN THE EYE}

NO is an exceptionally well-characterized signaling molecule, with important roles in a wide variety of physiological and pathophysiological processes, including cardiovascular homeostasis, neuronal function, and inflammation. NO is synthesized from L-arginine by a family of three enzymes referred to as NO synthases (NOSs) (Figure 1) (Moncada and Higgs, 1993). NOS2, or inducible NOS, was first identified in macrophages but has since been detected in a wide variety of cells exposed to endotoxin and cytokines. Following bacterial infection, especially with gramnegative organisms, high levels of NO are produced by NOS2. NOS1 and NOS3 were initially described to be constitutively expressed in neuronal cells and endothelial cells, respectively 


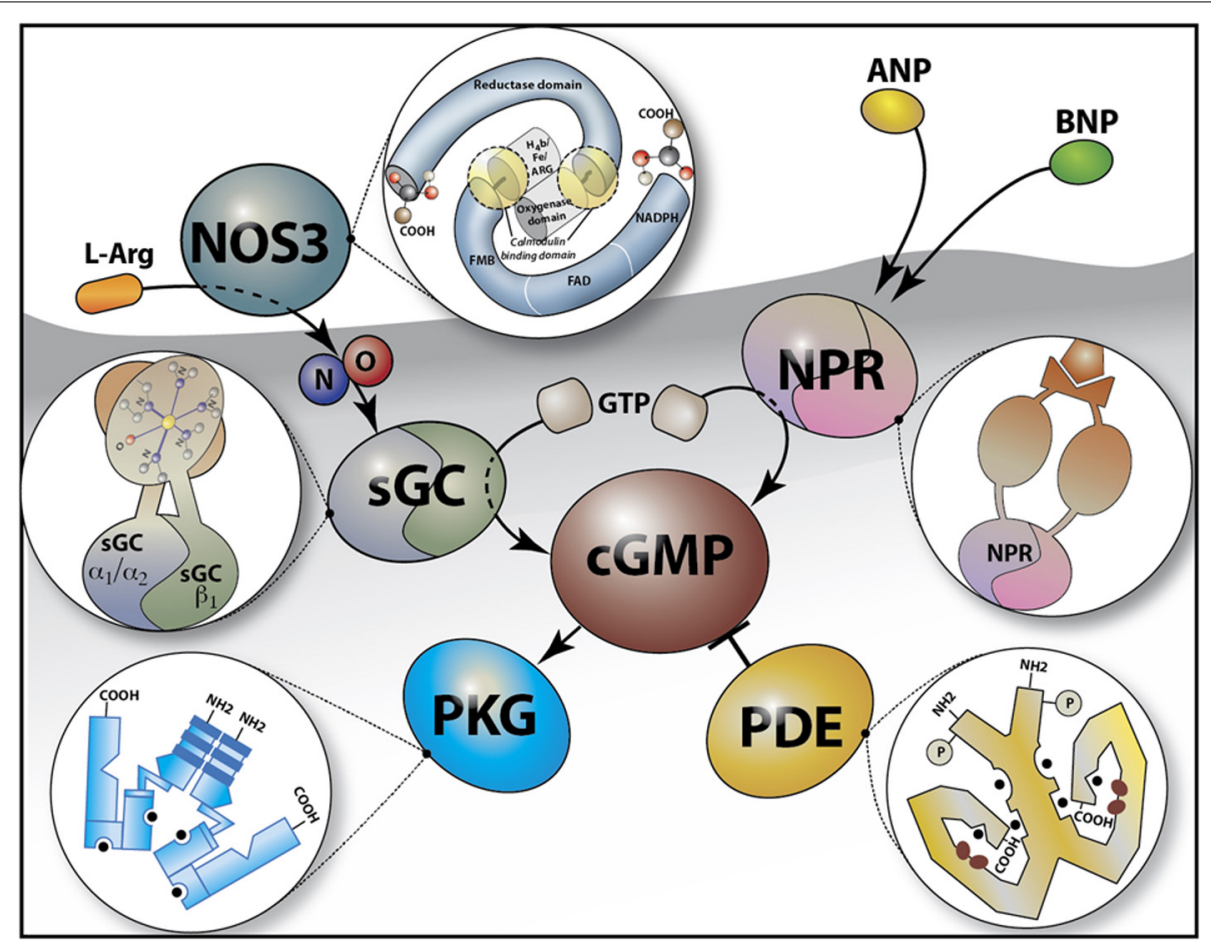

FIGURE 1 | Schematic of the Cyclic GMP (cGMP) signaling pathway. cGMP is synthesized from GTP by soluble guanylate cyclases (sGC $\alpha_{1} \beta_{1}$ or $s G \alpha_{2} \beta_{1}$ ) in response to nitric oxide (NO) e.g., as generated by the conversion of L-arginine (L-Arg) by NO synthase 3 (NOS3), or by the membrane guanylate cyclase (natriuretic peptide) receptors (NPR) which are activated by peptide hormones [e.g., atrial natriuretic peptide (ANP) and B-type natriuretic peptide (BNP)]. cGMP binds to and activates cGMP-dependent protein kinase G (PKG) and is hydrolyzed by phosphodiesterases (such as PDE5, the target for sildenafil). The insets depict a schematic overview of the structure of NOS3, NPR, PKG, PDE, and sGC.
(Moncada and Higgs, 1993). Under physiological conditions, the low levels of NO produced by the two constitutive $\mathrm{Ca}^{2+}$ dependent enzymes NOS1 and NOS3 have diverse functions ranging from neurotransmission and vasodilatation to inhibition of platelet adhesion and aggregation. NO, is an important modulator of smooth muscle function and all three NOS isoforms are expressed in the eye (Table 1). Multiple studies have reported on the ability of NO to modulate resistance in the AqH outflow pathway and IOP (see "NO-cGMP-mediated regulation of IOP: implications for POAG" below). Therefore, NO is an attractive candidate as a factor that could modify both mechanical and vascular events in POAG pathogenesis.

NO has numerous targets, reacting with a variety of intracellular and extracellular molecules typically via thiol groups or transition metal centers (Chiamvimonvat et al., 1995; Torres et al., 1995; Davis et al., 2001; Jaffrey et al., 2001; Stamler et al., 2001). A major target of NO is the obligate heterodimer soluble guanylate cyclase (sGC) (Mergia et al., 2003, 2006; Nimmegeers et al., 2007; Vermeersch et al., 2007; Buys et al., 2008), a hemecontaining heterodimeric enzyme, consisting of one $\alpha$ and one $\beta$ subunit (Figure 1). cGMP interacts with a variety of effector proteins including cGMP-dependent protein kinases (PKGs), cGMP-regulated phosphodiesterases (PDE's), and ion channels. cGMP is also synthesized by receptor guanylate cyclases that are activated by NPs (NPRs, Figure 1). However, cGMP produced by NPRs and sGC may have differential effects, possibly due to differential spatiotemporal distributions of cGMP produced by the two guanylate cyclase families (Su et al., 2005; Castro et al., 2006; Piggott et al., 2006).

Two functional isoforms of sGC exist: sGC $\alpha_{1} \beta_{1}$, the predominant isoform in most tissues (Mergia et al., 2003), and sGC $\alpha_{2} \beta_{1}$ (Hobbs, 1997; Russwurm et al., 1998; Bamberger et al., 2001). sGC $\alpha$ and $\beta$ subunits were shown to be expressed in several anatomical sites relevant for glaucoma (Table 1 and Figure 2). sGC activity was detected in rabbit (Haberecht et al., 1998), rat (Kajimura et al., 2003), turtle (Blute et al., 1998), and mouse retina (Blom et al., 2012; Buys et al., 2013). sGC is expressed both in retinal ganglion cells and photoreceptors and in the vascular smooth muscle layer of retinal arterioles. Finally, and most relevant to the potential ability of NO-sGC to modulate AqH outflow, sGC is abundantly expressed in isolated human TM cells (Ellis et al., 2009) and in both human and mouse CM (Buys et al., 2013). Also NP-activated membrane bound guanylate cyclase are expressed in various ocular tissues (see "NP receptors and their effects on IOP" below and Table 1).

\section{NO-cGMP-MEDIATED REGULATION OF IOP: IMPLICATIONS FOR POAG}

Multiple studies have yielded evidence suggesting that NO-cGMP signaling regulates AqH outflow and IOP. For example, both an NO donor and a cGMP-analog decreased IOP (Kotikoski et al., 2002) and increased outflow facility in rabbits (Kotikoski 
Table 1 | Ocular localization of nitric oxide synthase (NOS), soluble guanylate cyclase (sGC), and NP receptors (NPR).

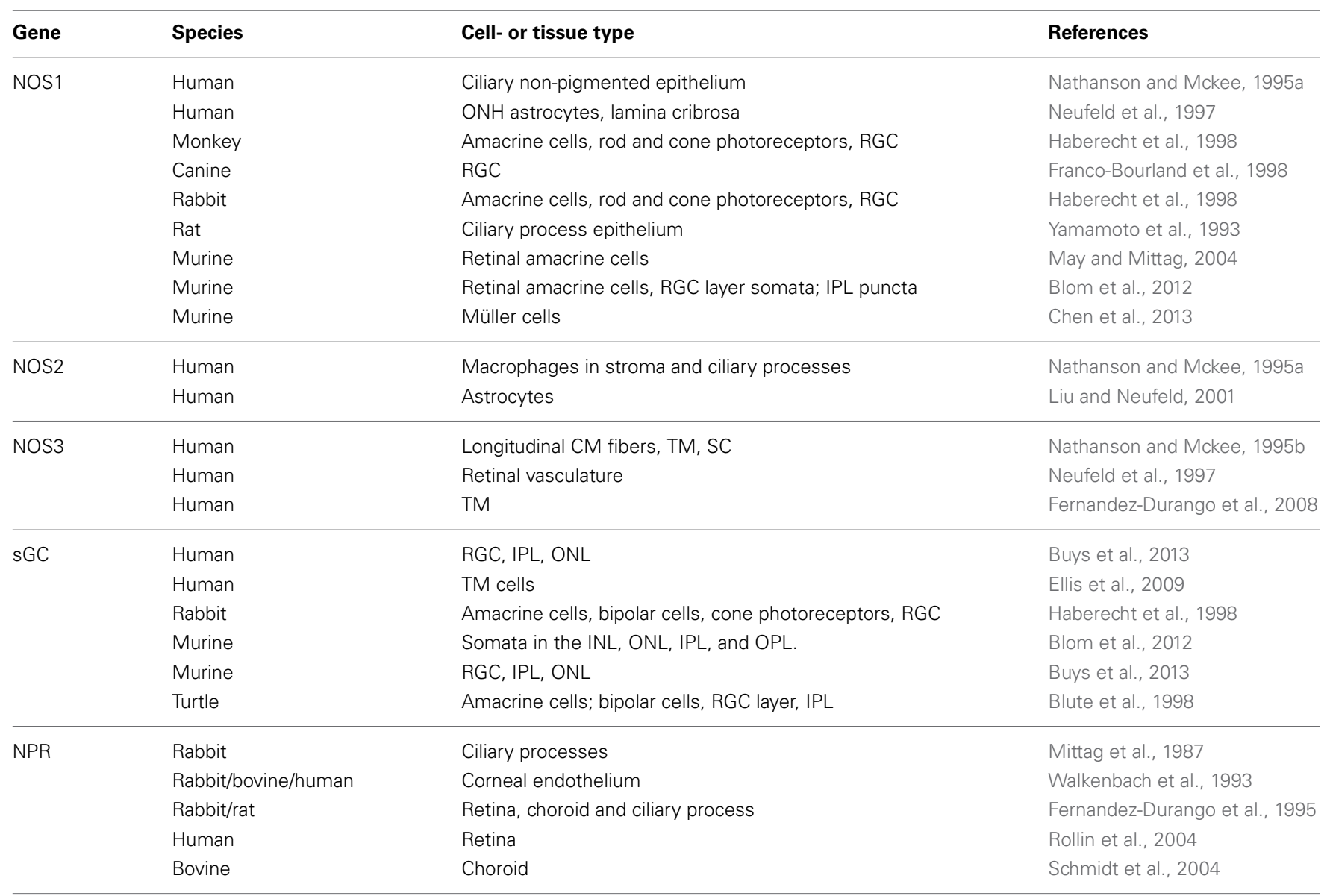

ONH, optic nerve head; RGC, retinal ganglion cell; IPL, inner plexiform layer; CM, ciliary muscle; TM, trabecular meshwork; SC, Schlemm's canal; ONL, outer nuclear layer; INL, inner nuclear layer; OPL, outer plexiform layer.

et al., 2003). The NO-induced increase in outflow facility was impaired by treating perfused porcine eyes with the sGC inhibitor $1 \mathrm{H}-[1,2,4]$ oxadiazolo[4,3-a] quinoxalin-1-1 (ODQ), suggesting that the effects of $\mathrm{NO}$ on outflow are cGMP-dependent (Ellis et al., 2009). The non-isoform specific NOS-inhibitor LNG-Nitroarginine methyl ester (L-NAME) decreased and an $\mathrm{NO}$-donor compound increased $\mathrm{AqH}$ flow rate in perfused human donor eyes. This increase in flow was associated with an increase in cGMP levels measured in the perfusate, again suggesting a central role for sGC and cGMP in the ability of NO to modulate outflow (Schneemann et al., 2002). Accordingly, NOdonor compounds lower IOP (Nathanson, 1988, 1992; Schuman et al., 1994; Behar-Cohen et al., 1996; Krauss et al., 2011) and enhance tissue oxygenation of the optic nerve head in preclinical animal models (Khoobehi et al., 2011). Overexpressing NOS3 in mice lowers IOP by increasing pressure-dependent drainage (Stamer et al., 2011), confirming previous reports suggesting that the ability of NO to lower IOP is mediated by a decrease in the $\mathrm{AqH}$ resistance rather than a change in the rate of $\mathrm{AqH}$ secretion (Nathanson and Mckee, 1995b). Other possible mechanisms by which NO and cGMP can modulate outflow include regulation of Schlemm's canal cell volume (Dismuke et al., 2008; Ellis et al., 2010) and TM cell volume (Dismuke et al., 2009).
Impaired NO-cGMP signaling has been implicated in POAG. For example, NO metabolites and cGMP levels were lower in both plasma and AqH samples from POAG patients than in those from individuals without POAG (Galassi et al., 2000, 2004; Doganay et al., 2002). Also, NADPH-diaphorase (NADPH-d) reactivity, a marker for NO production, was decreased in TM, SC, and anterior longitudinal CM fibers isolated from POAG eyes (Nathanson and Mckee, 1995a) and serum levels of L-arginine analogs (endogenous NOS inhibitors) were found to be elevated in patients with advanced glaucoma (Javadiyan et al., 2012). In addition, NOS3 gene variants were associated with POAG in women (see "Genetics of POAG" below Kang et al., 2010; Magalhaes Da Silva et al., 2012). Together, these studies suggest that impaired NO-cGMP signaling can contribute to the etiology of POAG, identifying the NO-cGMP signaling pathway as a potential therapeutic target for POAG. However, the molecular mechanisms mediating cGMP's effects in the eye, and exactly how NO-cGMP signaling regulates IOP or impacts optic neuropathy remain unclear.

It is important to recognize that the role of NO-cGMP signaling in the eye is likely complex with physiological and pathophysiological effects. For example, contrary to the observations described above that NO lowers IOP, topical application of the 


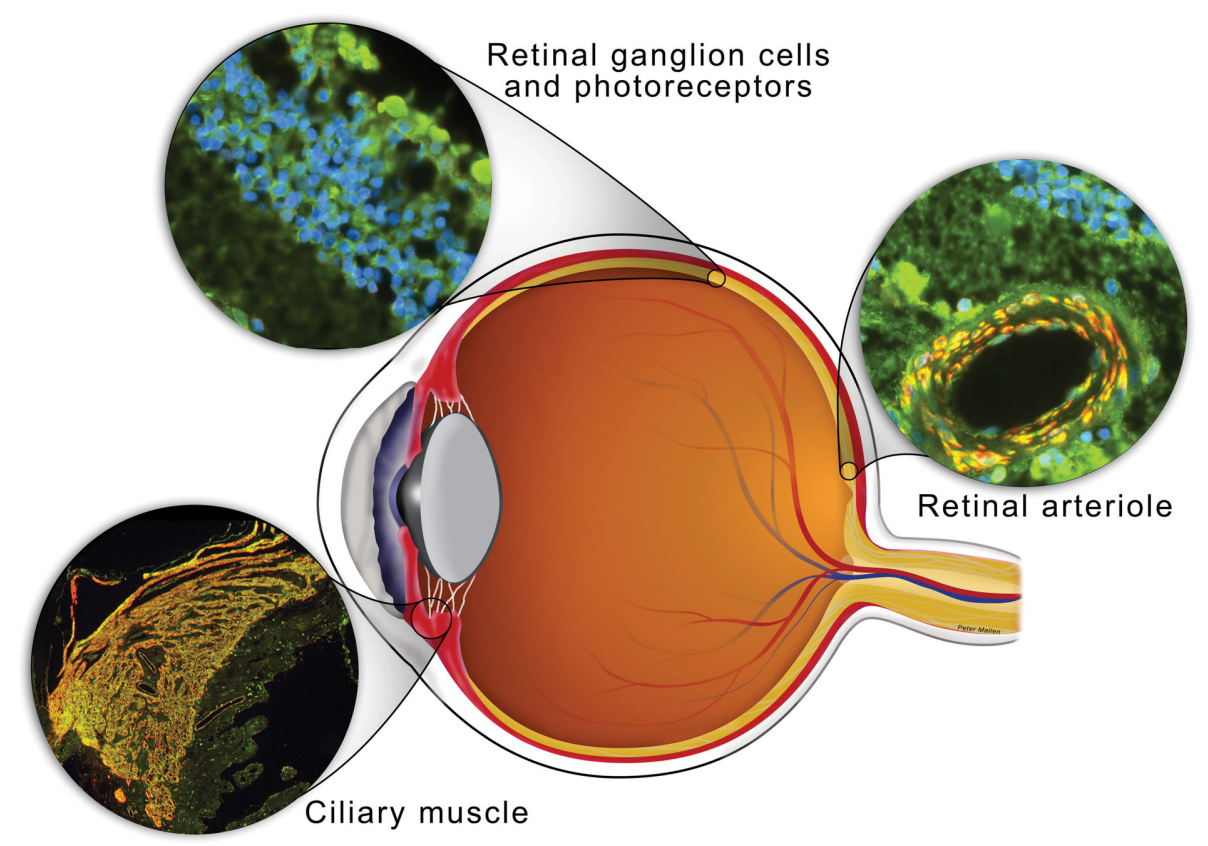

FIGURE 2 | Schematic of the eye with anatomical sites relevant for the development of POAG in which SGC is expressed indicated. Sections through retinal ganglion cells, ciliary muscle and a retinal arteriole from a human eye were stained for $\mathrm{sGC} \alpha_{1}$ (green), $\alpha$-smooth muscle actin (red), and/or DAPI nucleic acid stain (blue). Both $s G C \alpha_{1}$ and
sGC $\beta_{1}$ (not shown) co-localized with a-smooth muscle actin in ciliary muscle and the smooth muscle cell layer of a retinal arteriole (yellow in merged images). In addition, $\mathrm{sGC} \alpha_{1}$ and $\mathrm{sGC} \beta_{1}$ (not shown) expression was detected histologically in the outer nuclear layer, inner nuclear layer, and ganglion cell layer of the retina.
NOS-inhibitor L-NAME reduced IOP in a rabbit model of ocular hypertension (Giuffrida et al., 2003). This reduction of IOP, observed only in hypertensive eyes and not normotensive controls, was suggested to be associated with a decreased formation of AqH production (Giuffrida et al., 2003). Opposing effects of cGMP itself on $\mathrm{AqH}$ dynamics have been reported: $\mathrm{AqH}$ flow rate decreased after intravitreal administration of the cell permeable cGMP analog 8-Br-cGMP but increased after intra-cameral administration of 8 -Br-cGMP, underscoring that the route of administration of any drug aimed at lowering IOP or preventing POAG progression may significantly determines its therapeutic efficacy (Kee et al., 1994).

\section{NO MODULATES RGC VIABILITY}

NO can also exert a direct neurotoxic effect on RGC's (Morgan et al., 1999; Takahata et al., 2003). For example, in acute angleclosure glaucoma patients, higher levels of $\mathrm{NO}$ in $\mathrm{AqH}$ were postulated to contribute to RGC and optic nerve damage (Chang et al., 2000; Chiou et al., 2001). Similarly, in a rat model of chronic glaucoma, elevated retinal NOS1 expression was suggested to contribute to cytotoxicity and selective RGC loss (Park et al., 2007). Furthermore, NO generated by NOS2 can contribute to RGC death seen in response to increased IOP: treatment of rats with chronically elevated IOP with an inhibitor of NOS2 prevented RGC loss (Neufeld et al., 1999, 2002). More clinically relevant, expression of NOS2 was increased in the TM of POAG patients and activity of NOS2 in the TM of patients with POAG was reported to be proportional to the observed visual field defects
(Fernandez-Durango et al., 2008). Together, these data could be interpreted to suggest that inhibiting NOS activity may be useful for the treatment of glaucoma by protecting RGCs from stress (e.g., as associated with elevated IOP). However, as described in the studies referred to above, there is ample evidence that impaired NO-cGMP signaling contributes to the pathogenesis of POAG. Together with the fact that NO has multiple downstream targets, of which sGC is arguably a predominant one, these observations support focusing on sGC and cGMP as therapeutic targets in POAG (see "The NO-cGMP pathway as a therapeutic target for POAG" below).

\section{MODULATION OF TM AND CM CONTRACTILITY BY NO-cGMP AND ITS RELEVANCE IN IOP REGULATION}

It is generally accepted that the TM and CM are active structures rather than passive filters. The CM is a smooth-muscle like structure and the TM contains contractile smooth-muscle-specific alpha-actin filaments. Both are involved in fine-tuning the regulation of AqH outflow (Erickson-Lamy et al., 1991; Wiederholt, 1998; Wiederholt et al., 2000). Several studies (reviewed in Wiederholt et al., 2000) have suggested the existence of a functional antagonism between the TM and the CM, and TM resistance may be regulated by contractile state of CM (Nathanson and Mckee, 1995b): contraction of the CM would decrease TM resistance, increase AqH outflow and decrease IOP.

Alterations in smooth muscle contractility have previously been implicated in glaucoma. For example, RhoA-Rho kinase-mediated signaling, which regulates the phosphorylation 
status of myosin light chain, thereby directly influencing TM contraction, was reported to influence $\mathrm{AqH}$ drainage (Russ et al., 2010). Inhibiting Rho kinase, an enzyme that plays a critical role in regulating the contractile tone of smooth muscle tissues, increased $\mathrm{AqH}$ outflow in various animal models (Honjo et al., 2001; Rao and Epstein, 2007; Lu et al., 2008). The ability of Rhokinase inhibitors to lower IOP is currently being tested in clinical trials (Chen et al., 2011; Tanihara et al., 2013).

The presence of NOS3 and sGC in the CM and TM (Table 1) suggest that the NO-sGC pathway may modulate outflow resistance by regulating $\mathrm{CM}$ and $\mathrm{TM}$ contractility. In fact, both NO-donor compounds and a cGMP analog were previously demonstrated to regulate the contractile state of bovine CM and TM in organ bath experiments (Wiederholt et al., 1994; Masuda et al., 1997; Kamikawatoko et al., 1998). The ability of NO-cGMP to regulate smooth muscle cell relaxation is well known. For example, vascular reactivity was attenuated in NOS3 mutant mice (Atochin et al., 2007) and in sGC $\alpha_{1}^{-/-}$mice (Mergia et al., 2006; Nimmegeers et al., 2007). NO-cGMP signaling (facilitating smooth muscle relaxation Surks et al., 1999) and RhoA-Rho kinase signaling (causing smooth muscle contraction Bennett et al., 1988) have opposing effects on smooth muscle function and NO-cGMP signaling controls activity of the RhoA-Rho kinase pathway (Sauzeau et al., 2003). Together, these findings raise the possibility that impaired NO-cGMP signaling, previously suggested to participate in the regulation of AqH outflow and IOP (see "NO-cGMP-mediated regulation of IOP: implications for POAG" above) has a similar impact on $\mathrm{AqH}$ drainage as does increased RhoA-signaling: both could result in augmented contractility of the smooth muscle-like CM, thereby potentially decreasing AqH drainage and increasing IOP (Honjo et al., 2001).

There is, however, an apparent paradox in the dynamic regulation of IOP by the CM and the role of NO-cGMP therein: impaired NO-cGMP signaling would be expected to result in a decreased ability of the SMC-like CM to relax, just as it does in other SMC-like structures (Mergia et al., 2006; Friebe et al., 2007; Nimmegeers et al., 2007; Vanneste et al., 2007; Decaluwe et al., 2010), and hence decrease TM resistance. Importantly, there are two types of CM in humans: circular, involved in accommodation, and longitudinal (Flugel et al., 1990; Sharif et al., 2004). The effect of CM contraction and relaxation on IOP is not uniform: the circular and longitudinal components of the CM appear to have opposite roles in controlling IOP. Contraction of the circular muscle via muscarinic stimulation (e.g., in response to pilocarpine) causes tightening of the trabecular ring leading to an opening of the trabecular juxtacanalicular tissue, decreased resistance, and increased outflow facility, ultimately lowering IOP (Kaufman, 2008). On the other hand, there is evidence that contraction of the longitudinal muscle can impair outflow and increase IOP. The latter was demonstrated in patients that suffered significant blunt trauma where the circular CM is disabled without affecting the longitudinal muscle. When these patients were treated with pilocarpine, the contraction of the longitudinal muscle paradoxically increased IOP (Bleiman and Schwartz, 1979). Therefore, relaxation of the posterior longitudinal muscle in the CM (e.g., with Rho-kinase inhibitors Honjo et al.,
2001) likely has an outflow enhancing effect, lowering IOP. On the other hand, decreased relaxation of longitudinal CM fibers associated with impaired NO-cGMP signaling (e.g., in sGC $\alpha_{1}^{-/-}$mice, see "sGC-deficient mice: a model of elevated IOP and POAG" below), would result in increased IOP. In addition, repeated contraction and NO-mediated relaxation of any CM component may decreases outflow resistance and lower IOP, likely due to a direct mechanical effect on the TM. Lack of NO-sGC-cGMP signaling in the CM may prevent flushing of the TM, possibly resulting in altered (increased) outflow resistance.

\section{THE NO-cGMP PATHWAY AS A THERAPEUTIC TARGET FOR POAG}

The NO-cGMP pathway can be perturbed by a variety of mechanisms. Decreases in NOS3 expression or uncoupling of NOS3 result in lower NO levels (Takimoto et al., 2005). Alternatively, NO bioavailability can be reduced by interaction of NO with reactive oxygen species (ROS) (Munzel et al., 2010). sGC itself can be converted to an NO-insensitive state as a consequence of increased oxidative stress: it is conceivable that the mechanism by which increased oxidative stress results in POAG (Majsterek et al., 2011a) may involve direct oxidation and inactivation of sGC (Stasch et al., 2006). Also, sGC expression can be repressed under pro-inflammatory conditions (Marro et al., 2008). The latter is relevant based on the hypothesis that inflammation contributes to the development of glaucoma (Vohra et al., 2013). Lastly, NO-cGMP signaling can be modulated by genetic variation (see "Genetics of POAG" below) (Kang et al., 2010, 2011; Ehret et al., 2011; Buys et al., 2013). Whether any of the mechanisms that alter activity of the NO-cGMP pathway contribute to the etiology of POAG remains a matter of active investigation. Nonetheless, the studies described here and in the "Modulation of TM and CM contractility by NO-cGMP and its relevance in IOP regulation" section certainly imply the potential usefulness of focusing on NO-cGMP signaling as a therapeutic approach to the treatment of POAG.

Various therapeutic agents have been and are being developed to enhance NO-sGC-cGMP signaling. NO-independent sGC stimulators are already being clinically tested and have been approved for treating cardiovascular disease (Ghofrani et al., 2013). These compounds could conceivably be developed to treat POAG. NO-independent and heme-independent sGC activators preferentially activate sGC when the heme is oxidized or missing (Stasch et al., 2006). The selectivity of sGC activators for oxidized/heme-free sGC could be exploited therapeutically to preferentially target diseased tissue (Boerrigter et al., 2007), especially since oxidative stress may have a pathogenic role in POAG (Majsterek et al., 2011a). Another advantage of specifically activating sGC is that it bypasses any toxicity associated with activating NOS (see "NO-cGMP-mediated regulation of IOP: implications for POAG" above). In addition, targeting sGC rather than NOS circumvents concerns related with reduced NO bioavailability (e.g., in a setting of increased oxidative stress) and allows for a more specific approach since the biological actions of NO are not only mediated by cGMP but also by cGMP-independent mechanisms. 
Other potential therapeutic approaches specifically aimed at cGMP signaling that may be developed for treatment of POAG include targeting other enzymes that control GMP levels and which are abundantly present in the eye, including cGMPcatabolizing PDE's (Francis et al., 2011) and NP activated membrane bound guanylate cyclades (see "NP receptors and their effects on IOP" below, Mckie et al., 2010). Pilot studies testing the ability of the PDE5 inhibitor sildenafil to lower IOP were not successful. A single oral dose of $50-100 \mathrm{mg}$ sildenafil failed to impact IOP in POAG patients (Grunwald et al., 2001) and healthy volunteers (Vobig et al., 1999; Sponsel et al., 2000), but did increase blood flow in both healthy subjects (Sponsel et al., 2000; Foresta et al., 2008) and patients with systemic vascular dysfunction (Koksal et al., 2005). Also chronic treatment with sildenafil (twice per week for 3 months) failed to impact IOP (Dundar et al., 2006). It is noteworthy that the cohorts in which the effect of sildenafil on IOP was studied were of limited size (5-15 subjects). It is conceivable that these studies were underpowered to detect small decreases in IOP associated with sildenafil treatment. This is a relevant concern since modest changes in IOP have been reported to impact POAG risk in humans. For example, a 2mmHg difference in IOP distinguished between progression and non-progression in POAG patients (Leske et al., 2007; Konstas et al., 2012). Also, most of the cohorts studied consisted of men only. In light of a possible gender-specificity of POAG (Vajaranant et al., 2010; Pasquale and Kang, 2011; Tsai et al., 2012) and the role of NO-cGMP signaling therein (Kang et al., 2010), it would be of interest to see whether preventing cGMP catabolism by PDE5 would impact IOP in women. Finally, the half-life of sildenafil is rather limited $(\sim 4 \mathrm{~h})$ (Smith et al., 2013). It may be worthwhile testing the effect on IOP of other PDE5 inhibitors with longer half-lives (e.g., tadalafil with a half-life of $\sim 17 \mathrm{~h} \mathrm{Smith} \mathrm{et} \mathrm{al.,}$ 2013) and/or performing a carefully controlled dose response experiment. Finally, various methods to deliver the drug should be tested. Whether pharmacological modulation of the activity of enzymes that ultimately modulate cGMP levels may prevent POAG progression remains to be determined.

\section{SGC-DEFICIENT MICE: A MODEL OF ELEVATED IOP AND POAG}

Mice lacking the $\alpha_{1}$ subunit of the NO receptor soluble guanylate cyclase $\left(\mathrm{sGC}_{1}^{-/-}\right.$mice) were recently reported to represent a novel and translatable animal model of POAG, characterized by thinning of the retinal nerve fiber layer (RNFL) and loss of optic nerve axons (Buys et al., 2013). The optic neuropathy associated with $\mathrm{sGC} \alpha_{1}$-deficiency was accompanied by modestly increased IOP, on average $2 \mathrm{mmHg}$ higher in $39 \pm 14$ weeks old female $\mathrm{sGC} \alpha_{1}^{-/-}$mice than in age-matched female wild-type (WT) mice. No IOP difference was detected between age-matched $15 \pm 6$ weeks old female sGC $\alpha_{1}^{-/-}$and age-matched WT mice: age was a predictor of elevated IOP in female $\mathrm{sGC}_{1}^{-/-}$but not in WT mice. The increase in IOP was accompanied by a decrease in $\mathrm{AqH}$ turnover in the context of an open iridocorneal angle: $\mathrm{sGC}_{1}^{-/-}$mice presented with a normal ciliary body, a well-defined TM, and a patent Schlemm's canal. In addition, spectral domain optical coherence tomography analysis of the iridocorneal angle did not reveal any evidence for angle-closure in sGC $\alpha_{1}^{-/-}$mice. Similarly, biomicroscopy did not reveal any evidence of exfoliation syndrome, pigment dispersion syndrome, or other conditions that could produce elevated IOP.

Highlighting the multi-faceted role of NO-cGMP signaling in ocular (patho)physiology, retinal vascular dysfunction was observed in $\mathrm{sGC}_{1}^{-/-}$mice. Other studies had postulated that vascular dysfunction contributes to the etiology of POAG (Henry et al., 1999; Feke and Pasquale, 2008; Su et al., 2008) and systemic vascular dysfunction had been previously reported in $\mathrm{sGC}_{1}^{-/-}$ mice (Nimmegeers et al., 2007; Atochin et al., 2010; Buys et al., 2012). Whether retinal vascular dysfunction underlies the retinal degeneration and optic neuropathy in $\mathrm{sGC} \alpha_{1}^{-/-}$mice remains to be determined. Vascular dysfunction may also contribute to the observed increases in IOP in $\mathrm{sGC}_{1}^{-/-}$mice, possibly by impairing uveolymphatic outflow (see "Intraocular pressure: a risk factor for POAG” above). Finally, it cannot be excluded that loss of RGCs in $\mathrm{sGC} \alpha_{1}^{-/-}$mice is caused by a direct effect of sGCdeficiency on RGCs, possibly modulating the susceptibility of RGCs to stress imposed by increased IOP or vascular dysfunction. Taken together, targeting sGC may represent a multi-pronged approach, aimed at lowering IOP, ameliorating vascular function, and protecting RGCs from stress-induced dysfunction and death. To test this hypothesis, additional studies, including in animal models of POAG, such as the $\mathrm{SGC}_{1}^{-/-}$mouse model, are required.

\section{GENETICS OF POAG}

First-degree relatives of glaucoma patients have a $22 \%$ risk of developing glaucoma versus a $2 \%$ lifetime risk of relatives of controls (Wolfs et al., 1998). In recent years, familial aggregation, genome wide and candidate gene association studies have uncovered an important genetic component to POAG (Table 2). Several dozen genetic loci have been linked to POAG (Fan et al., 2006). The role of many of the identified genes in the etiology of POAG, some of which were identified in single studies that need to be replicated, remains controversial. Among the genes identified to date, three are involved in the nitric oxide (NO)-cGMP system, highlighting a central role of this signaling pathway in the development of POAG. First, variants were identified in or near the genes encoding caveolin 1 and 2 (CAV1/CAV2) (Thorleifsson et al., 2010; Wiggs et al., 2011). Caveolins modulate the ability of NOS3 to generate NO (Mineo and Shaul, 2012). At least one variant in the CAV1/CAV2 locus was subsequently found to be associated with increased IOP (Van Koolwijk et al., 2012; Ozel et al., 2014). Second, A candidate gene association study in 527 incident cases and 1543 controls revealed interactions between NOS3 gene variants, potentially affecting expression and/or activity of NOS3, and high tension POAG in females (Kang et al., 2010). In addition, a functional NOS3 polymorphism (T-786C) was associated with POAG and appears to interact with gender and age in modulating the risk of POAG (Magalhaes Da Silva et al., 2012). The same variant also affects the interaction of systemic hypertension and cigarette smoking with POAG risk, highlighting the complex gene-environment interactions that impact the etiology of POAG (Kang et al., 2011). And 
Table 2 | POAG-associated genes.

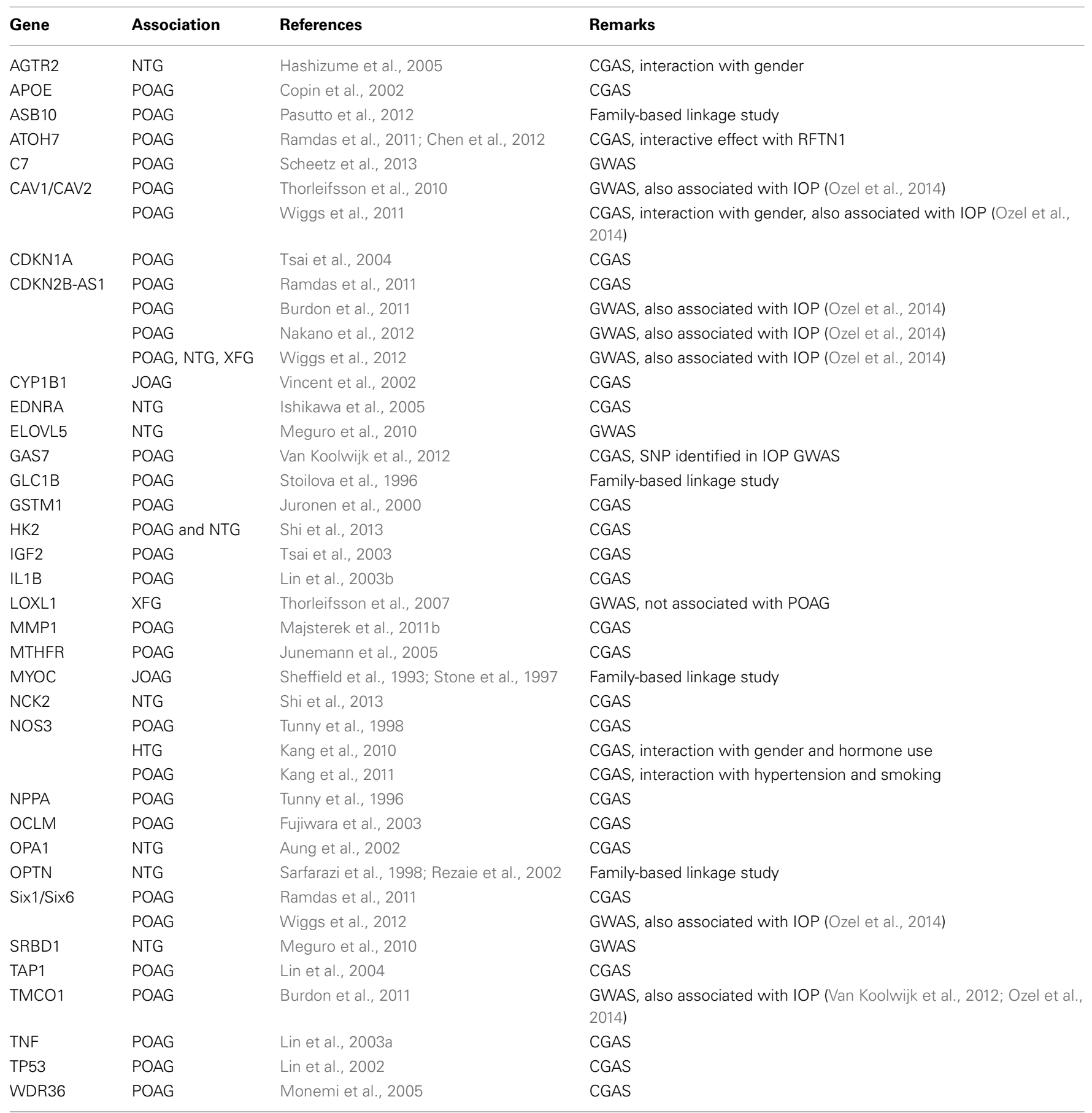

AGTR2, Angiotensin II receptor type 2; APOE, Apolipoprotein E; ASB10, ankyrin repeat and SOCS box-containing 1; ATOH7, atonal homolog 7; C7, complement component 7; CAV1, caveolin 1; CAV2, caveolin 2; CDKN1A, cyclin-dependent kinase inhibitor 1A; CDKN2B-AS1, CDKN2B antisense RNA 1; CGAS, candidate gene association study; CYP1B1, cytochrome P450 subfamily I polypeptide 1; EDNRA, endothelin receptor type A; ELOVL1, elongation of very-long-chain-fatty acids 1; GAS7, growth arrest-specific protein 7; GLC1B, glaucoma 1, open angle, B; GSTM1, glutathione S-transferase mu-1; GWAS, genome-wide association study; HK2, hexokinase 2; HTG, high-tension glaucoma; IGF2, insulin-like growth factor II; IL1B, interleukin 1-beta; IOP, intra-ocular pressure; JOAG, juvenile open angle glaucoma; LOXL1, Iysyl oxidase-like 1; MMP1, matrix metalloproteinase 1; MTHFR, 5, 10-methylenetetrahydrofolate reductase; MYOC, myocilin; NCK2, NCK adaptor protein 2; NOS3, nitric oxide synthase 3; NPPA, natriuretic peptide precursor; NTG, normal-tension glaucoma; OCLM, oculomedin; OPA1, optic atrophy 1; OPTN, optineurin; POAG, primary open angle glaucoma; RFTN1, raftlin lipid raft linker 1; Six1/Six6, six homeobox1/6; SRBD1, S1 RNA-Binding Domain-Containing Protein 1; TAP1, transporter ATP-binding cassette major histocompatibility complex 1; TMCO1, transmembrane and coiled-coil domains 1; TNF, tumor necrosis factor; TP53, tumor protein $p 53$; WDR36, WD repeat domain 36; XFG, exfoliation glaucoma. 
thirdly, in a recent candidate gene association study in POAG patients from the GLAUGEN cohort (Wiggs et al., 2011), a variant (rs11722059) was identified in the GUCY1A3/GUCY1B3 locus (containing the genes encoding the $\alpha_{1}$ and $\beta_{1}$ subunits of sGC, arranged in tandem) (Wiggs et al., 2011). Intriguingly, the association was only present in POAG characterized by early paracentral visual field loss (Buys et al., 2013). Early paracentral visual field loss is a subtype of POAG previously postulated to be associated with ocular vascular dysregulation (Park et al., 2011). This was a particularly interesting finding in light of the identification of $\mathrm{sGC} \alpha_{1}^{-/-}$mice with systemic and retinal vascular dysfunction, as a model of POAG with moderately elevated IOP: as described above, POAG patients with early paracentral visual field loss tend to have more frequent systemic vascular risk factors (Park et al., 2011, 2012), and low OPP is a risk factor for POAG (Leske, 2009; Cherecheanu et al., 2013). In addition, rs11722059 is in linkage disequilibrium with a GUCY1A3/GUCY1B3 variant associated with blood pressure in a large genome wide association study (GWAS) (Ehret et al., 2011). However, the extent to which vascular dysfunction contributes to glaucomatous optic neuropathy remains to be elucidated (Flammer et al., 2002; Vajaranant and Pasquale, 2012).

For neither the NOS3 or GUCY1A3/GUCY1B3 variants, an association with IOP was detected. Whether this truly means that there is no association with the identified variants remains unsure: it is conceivable that the GWAS and candidate gene association studies discussed were underpowered to detect small effect on IOP. For example, the GWAS in which the sGC blood pressure variant was identified included 200,000 subjects (Ehret et al., 2011). In contrast, the studies aimed at identifying associations with POAG and IOP (like systemic blood pressure a continuous variable) were much smaller in scope (hundreds to several thousand subjects).

\section{NP RECEPTORS AND THEIR EFFECTS ON IOP}

There are three NPs in mammals: atrial NP, B-type NP and Ctype NP (Potter et al., 2009). A separate gene encodes each NP, and mouse "knock out" experiments have shown that each NP has unique functions, although all members stimulate vasorelaxation. ANP and BNP are cardiac endocrine hormones that decrease blood pressure and volume. CNP is a paracrine-signaling molecule that stimulates long bone growth, causes bifurcation of neurons in the spinal cord and inhibits meiosis in the oocyte.

There are also three known NP peptide receptors (Potter, $2011 \mathrm{a}, \mathrm{b}, \mathrm{c})$. The natriuretic clearance receptor (NPR-C) controls the local concentration of all three natriuretic peptides through an undefined receptor-mediated internalization and degradation process, but it has also been reported to signal through a Gprotein-dependent pathway. The primary signaling receptor for ANP and BNP is guanylate cyclase-A (GC-A), which is also known as natriuretic peptide receptor-A or NPR1. It consists of an extracellular ligand-binding domain, a single membranespanning region and intracellular guanylate cyclase domain. GCB, also known at NPR-B or NPR2, is the primary signaling receptor for CNP and it is topologically and structurally similar to GC-A. The vast majority of NPs functions are mediated through elevation of intracellular cGMP concentrations synthesized by the guanylate cyclase domains of GC-A or GC-B.
Early studies reported that binding sites for ${ }^{125} \mathrm{I}$-ANP were found in rat and rabbit ciliary processes (Bianchi et al., 1986). Shortly thereafter, topical, intracameral and intravitreal application of ANP was shown to decrease IOP in rabbits (Sugrue and Viader, 1986). The pressure reductions were longer lasting with the intravitreal treatments but even the topical application reduced IOP. Additional studies found that ANP stimulated guanylate cyclase activity in ciliary processes of the rabbit eye and that intravitreous injection of ANP decreased IOP in the rabbit eye for up to $24 \mathrm{~h}$ (Mittag et al., 1987). The reduction of IOP by intravitreal ANP was later correlated to a decrease in AqH flow in the rabbit eye (Korenfeld and Becker, 1989).

Relatively low concentrations of CNP $(\sim 2 \mathrm{nmol} / \mathrm{L})$ were also shown to increase cGMP concentrations in the AqH of the rabbit eye and reduce IOP in rabbit eyes by a process associated with an increase in total outflow facility (Takashima et al., 1998). In the same study, CNP-like immunoreactivity was detected in rabbit and porcine $\mathrm{AqH}$ at about two-fold higher concentrations than that found in plasma. In a more recent study, CNP was shown to be a more potent reducer of IOP than ANP in rabbit eyes, and a ring-deleted analog of ANP that blocked binding to NPR$\mathrm{C}$ and increased the concentration of all endogenous natriuretic peptides, maintained IOP reductions longer that other natriuretic peptides (Fernandez-Durango et al., 1999). Thus, whether the reductions in IOP observed by early investigators were due to cross-activation of GC-B or whether activation of GC-B and GCA leads to decreased IOP is not known. Regardless, CNP is the most potent natriuretic peptide for reducing IOP in mammals, which suggests that the degradation resistant CNP analog developed for the treatment of achondroplasia may be an ideal peptidebased molecule to reduce IOP in the clinic (Lorget et al., 2012).

\section{CONCLUSION}

In conclusion, POAG remains a major cause of blindness in the USA and worldwide. The identification of new therapeutic targets for the treatment of POAG has been hampered by lack of understanding of the etiology of POAG and the limited number of animal models available that likely represent only a small subset of human POAG cases. There continues to be an urgent need for biomarkers that allow to detect/diagnose/track POAG progression and treatment efficacy. Also, the lack of a definitive cure underscores the need to develop novel therapeutic approaches for POAG.

Evidence obtained from animal models indicates that cGMP signaling plays an important role in POAG pathogenesis. These findings are supported by genetic studies of IOP and POAG risk in human subjects, highlighting the relevance of cGMP signaling in the development of POAG. Strategies aimed at modulating cGMP levels may constitute a pharmacological approach for a disease for which no definitive cure is currently available. However, additional studies are required to unequivocally determine the role of impaired cGMP signaling in POAG and to advance benchto-bedside translation of available cGMP-enhancing reagents.

\section{ACKNOWLEDGMENTS}

The authors thank Peter Mallen for generating the figures. Dr. Buys was supported by NIH/NEI 1R01EY022746-01. Dr. Pasquale was supported by a Harvard Medical School 
Distinguished Ophthalmology Scholar Award and by NIH/NEI RO1EY015473-10.

\section{REFERENCES}

Alward, W. L. (2000). The genetics of open-angle glaucoma: the story of GLC1A and myocilin. Eye 14 (Pt 3B), 429-436. doi: 10.1038/eye.2000.127

Anderson, M. G., Libby, R. T., Mao, M., Cosma, I. M., Wilson, L. A., Smith, R. S., et al. (2006). Genetic context determines susceptibility to intraocular pressure elevation in a mouse pigmentary glaucoma. BMC Biol. 4, 20. doi: 10.1186/17417007-4-20

Arevalo, J. F., Munguia, D., Faber, D., Friedlander, S. M., Quiceno, J. I., Rahhal, F. M., et al. (1996). Correlation between intraocular pressure and CD4+ Tlymphocyte counts in patients with human immunodeficiency virus with and without cytomegalovirus retinitis. Am. J. Ophthalmol. 122, 91-96.

Atochin, D. N., Wang, A., Liu, V. W., Critchlow, J. D., Dantas, A. P., Looft-Wilson, R., et al. (2007). The phosphorylation state of eNOS modulates vascular reactivity and outcome of cerebral ischemia in vivo. J. Clin. Invest. 117, 1961-1967. doi: 10.1172/JCI29877

Atochin, D. N., Yuzawa, I., Li, Q., Rauwerdink, K. M., Malhotra, R., Chang, J., et al. (2010). Soluble guanylate cyclase alphalbetal limits stroke size and attenuates neurological injury. Stroke 41, 1815-1819. doi: 10.1161/STROKEAHA.109.577635

Aung, T., Ocaka, L., Ebenezer, N. D., Morris, A. G., Krawczak, M., Thiselton, D. L., et al. (2002). A major marker for normal tension glaucoma: association with polymorphisms in the OPAl gene. Hum. Genet. 110, 52-56. doi: 10.1007/s00439-001-0645-7

Bamberger, A. M., Koglin, M., Kempfert, J., Loning, T., Scholz, H., and Behrends, S. (2001). Expression and tissue localization of soluble guanylyl cyclase in the human placenta using novel antibodies directed against the alpha(2) subunit. J. Clin. Endocrinol. Metab. 86, 909-912. doi: 10.1210/jcem.86.2.7409

Behar-Cohen, F. F., Goureau, O., D’hermies, F., and Courtois, Y. (1996). Decreased intraocular pressure induced by nitric oxide donors is correlated to nitrite production in the rabbit eye. Invest. Ophthalmol. Vis. Sci. 37, 1711-1715.

Bengtsson, B., Leske, M. C., Hyman, L., and Heijl, A. (2007). Fluctuation of intraocular pressure and glaucoma progression in the early manifest glaucoma trial. Ophthalmology 114, 205-209. doi: 10.1016/j.ophtha.2006.07.060

Bennett, J. P., Cross, R. A., Kendrick-Jones, J., and Weeds, A. G. (1988). Spatial pattern of myosin phosphorylation in contracting smooth muscle cells: evidence for contractile zones. J. Cell Biol. 107, 2623-2629. doi: 10.1083/jcb.107.6.2623

Bianchi, C., Anand-Srivastava, M. B., De Lean, A., Gutkowska, J., Forthomme, D., Genest, J., et al. (1986). Localization and characterization of specific receptors for atrial natriuretic factor in the ciliary processes of the eye. Curr. Eye Res. 5, 283-293. doi: 10.3109/02713688609020054

Bleiman, B. S., and Schwartz, A. L. (1979). Paradoxical intraocular pressure response to pilocarpine. A proposed mechanism and treatment. Arch. Ophthalmol. 97, 1305-1306. doi: 10.1001/archopht.1979.01020020047010

Blom, J., Giove, T., Deshpande, M., and Eldred, W. D. (2012). Characterization of nitric oxide signaling pathways in the mouse retina. J. Comp. Neurol. 520, 4204-4217. doi: $10.1002 /$ cne. 23148

Blute, T. A., Velasco, P., and Eldred, W. D. (1998). Functional localization of soluble guanylate cyclase in turtle retina: modulation of cGMP by nitric oxide donors. Vis. Neurosci. 15, 485-498. doi: 10.1017/S0952523898153075

Boerrigter, G., Costello-Boerrigter, L. C., Cataliotti, A., Lapp, H., Stasch, J. P., and Burnett, J. C., Jr. (2007). Targeting heme-oxidized soluble guanylate cyclase in experimental heart failure. Hypertension 49, 1128-1133. doi: 10.1161/HYPERTENSIONAHA.106.083832

Bonomi, L., Marchini, G., Marraffa, M., Bernardi, P., Morbio, R., and Varotto, A. (2000). Vascular risk factors for primary open angle glaucoma: the Egna-Neumarkt Study. Ophthalmology 107, 1287-1293. doi: 10.1016/S01616420(00)00138-X

Burdon, K. P., Macgregor, S., Hewitt, A. W., Sharma, S., Chidlow, G., Mills, R. A., et al. (2011). Genome-wide association study identifies susceptibility loci for open angle glaucoma at TMCO1 and CDKN2B-AS1. Nat. Genet. 43, 574-578. doi: $10.1038 /$ ng. 824

Buys, E. S., Ko, Y. C., Alt, C., Hayton, S. R., Jones, A., Tainsh, L. T., et al. (2013). Soluble guanylate cyclase alphal-deficient mice: a novel murine model for primary open angle glaucoma. PLOS ONE 8:e60156. doi: 10.1371/journal.pone. 0060156
Buys, E. S., Raher, M. J., Kirby, A., Mohd, S., Baron, D. M., Hayton, S. R., et al. (2012). Genetic modifiers of hypertension in soluble guanylate cyclase alpha1deficient mice. J. Clin. Invest. 122, 2316-2325. doi: 10.1172/JCI60119

Buys, E. S., Sips, P., Vermeersch, P., Raher, M. J., Rogge, E., Ichinose, F., et al. (2008). Gender-specific hypertension and responsiveness to nitric oxide in $\mathrm{sGC}\{$ alpha $\} 1$ knockout mice. Cardiovasc. Res. 79, 179-186. doi: 10.1093/cvr/cvn068

Carbonaro, F., Andrew, T., Mackey, D. A., Young, T. L., Spector, T. D., and Hammond, C. J. (2009). Repeated measures of intraocular pressure result in higher heritability and greater power in genetic linkage studies. Invest. Ophthalmol. Vis. Sci. 50, 5115-5119. doi: 10.1167/iovs.09-3577

Castro, L. R., Verde, I., Cooper, D. M., and Fischmeister, R. (2006). Cyclic guanosine monophosphate compartmentation in rat cardiac myocytes. Circulation 113, 2221-2228. doi: 10.1161/CIRCULATIONAHA.105.599241

Chang, C. J., Chiang, C. H., Chow, J. C., and Lu, D. W. (2000). Aqueous humor nitric oxide levels differ in patients with different types of glaucoma. J. Ocul. Pharmacol. Ther. 16, 399-406. doi: 10.1089/jop.2000.16.399

Chen, C., Xu, Y., Zhang, J., Zhu, J., Hu, N., and Guan, H. (2013). Altered expression of nNOS/NIDD in the retina of a glaucoma model of DBA/2J mice and the intervention by nNOS inhibition. J. Mol. Neurosci. 51, 47-56. doi: 10.1007/s12031-012-9943-x

Chen, J. H., Wang, D., Huang, C., Zheng, Y., Chen, H., Pang, C. P., et al. (2012). Interactive effects of ATOH7 and RFTN1 in association with adult-onset primary open-angle glaucoma. Invest. Ophthalmol. Vis. Sci. 53, 779-785. doi: 10.1167/iovs.11-8277

Chen, J., Runyan, S. A., and Robinson, M. R. (2011). Novel ocular antihypertensive compounds in clinical trials. Clin. Ophthalmol. 5, 667-677. doi: 10.2147/OPTH.S15971

Cherecheanu, A. P., Garhofer, G., Schmidl, D., Werkmeister, R., and Schmetterer, L. (2013). Ocular perfusion pressure and ocular blood flow in glaucoma. Curr. Opin. Pharmacol. 13, 36-42. doi: 10.1016/j.coph.2012.09.003

Chiamvimonvat, N., O’Rourke, B., Kamp, T. J., Kallen, R. G., Hofmann, F., Flockerzi, V., et al. (1995). Functional consequences of sulfhydryl modification in the pore-forming subunits of cardiovascular $\mathrm{Ca} 2+$ and $\mathrm{Na}+$ channels. Circ. Res. 76, 325-334. doi: 10.1161/01.RES.76.3.325

Chiou, S. H., Chang, C. J., Hsu, W. M., Kao, C. L., Liu, J. H., Chen, W. L., et al. (2001). Elevated nitric oxide level in aqueous humor of patients with acute angle-closure glaucoma. Ophthalmologica 215, 113-116. doi: $10.1159 / 000050840$

Clark, A. F., Wilson, K., De Kater, A. W., Allingham, R. R., and Mccartney, M. D. (1995). Dexamethasone-induced ocular hypertension in perfusion-cultured human eyes. Invest. Ophthalmol. Vis. Sci. 36, 478-489.

Copin, B., Brezin, A. P., Valtot, F., Dascotte, J. C., Bechetoille, A., and Garchon, H. J. (2002). Apolipoprotein E-promoter single-nucleotide polymorphisms affect the phenotype of primary open-angle glaucoma and demonstrate interaction with the myocilin gene. Am. J. Hum. Genet. 70, 1575-1581. doi: 10.1086/340733

Davis, K. L., Martin, E., Turko, I. V., and Murad, F. (2001). Novel effects of nitric oxide. Annu. Rev. Pharmacol. Toxicol. 41, 203-236. doi: 10.1146/annurev.pharmtox.41.1.203

Decaluwe, K., Nimmegeers, S., Thoonen, R., Buys, E., Brouckaert, P., and Van De Voorde, J. (2010). In vitro and in vivo studies on the importance of the soluble guanylyl cyclase alphal subunit in penile erection. World J. Urol. 28, 643-650. doi: 10.1007/s00345-010-0509-7

De Voogd, S., Ikram, M. K., Wolfs, R. C., Jansonius, N. M., Hofman, A., and De Jong, P. T. (2005). Incidence of open-angle glaucoma in a general elderly population: the Rotterdam Study. Ophthalmology 112, 1487-1493. doi: 10.1016/j.ophtha.2005.04.018

Dismuke, W. M., Mbadugha, C. C., and Ellis, D. Z. (2008). NO-induced regulation of human trabecular meshwork cell volume and aqueous humor outflow facility involve the BKCa ion channel. Am. J. Physiol. Cell Physiol. 294, C1378-C1386. doi: 10.1152/ajpcell.00363.2007

Dismuke, W. M., Sharif, N. A., and Ellis, D. Z. (2009). Human trabecular meshwork cell volume decrease by NO-independent soluble guanylate cyclase activators YC-1 and BAY-58-2667 involves the BKCa ion channel. Invest. Ophthalmol. Vis. Sci. 50, 3353-3359. doi: 10.1167/iovs.08-3127

Doganay, S., Evereklioglu, C., Turkoz, Y., and Er, H. (2002). Decreased nitric oxide production in primary open-angle glaucoma. Eur. J. Ophthalmol. 12, 44-48.

Dundar, S. O., Dayanir, Y., Topaloglu, A., Dundar, M., and Kocak, I. (2006). Effect of sildenafil on ocular hemodynamics in 3 months regular use. Int. J. Impot. Res. 18, 282-286. doi: $10.1038 /$ sj.ijir.3901416 
Ehret, G. B., Munroe, P. B., Rice, K. M., Bochud, M., Johnson, A. D., Chasman, D. I., et al. (2011). Genetic variants in novel pathways influence blood pressure and cardiovascular disease risk. Nature 478, 103-109. doi: 10.1038/nature10405

Ellis, D. Z., Dismuke, W. M., and Chokshi, B. M. (2009). Characterization of soluble guanylate cyclase in NO-induced increases in aqueous humor outflow facility and in the trabecular meshwork. Invest. Ophthalmol. Vis. Sci. 50, 1808-1813. doi: 10.1167/iovs.08-2750

Ellis, D. Z., Sharif, N. A., and Dismuke, W. M. (2010). Endogenous regulation of human Schlemm's canal cell volume by nitric oxide signaling. Invest. Ophthalmol. Vis. Sci. 51, 5817-5824. doi: 10.1167/iovs.09-5072

Erickson-Lamy, K., Rohen, J. W., and Grant, W. M. (1991). Outflow facility studies in the perfused human ocular anterior segment. Exp. Eye Res. 52, 723-731. doi: 10.1016/0014-4835(91)90024-9

Ethier, C. R., Kamm, R. D., Palaszewski, B. A., Johnson, M. C., and Richardson, T. M. (1986). Calculations of flow resistance in the juxtacanalicular meshwork. Invest. Ophthalmol. Vis. Sci. 27, 1741-1750.

Fan, B. J., Wang, D. Y., Lam, D. S., and Pang, C. P. (2006). Gene mapping for primary open angle glaucoma. Clin. Biochem. 39, 249-258. doi: 10.1016/j.clinbiochem.2005.11.001

Fautsch, M. P., and Johnson, D. H. (2006). Aqueous humor outflow: what do we know? Where will it lead us? Invest. Ophthalmol. Vis. Sci. 47, 4181-4187. doi: 10.1167/iovs.06-0830

Feke, G. T., Hazin, R., Grosskreutz, C. L., and Pasquale, L. R. (2011). Effect of brimonidine on retinal blood flow autoregulation in primary open-angle glaucoma. J. Ocul. Pharmacol.7, 347-352. doi: 10.1089/jop.2011.0014

Feke, G. T., and Pasquale, L. R. (2008). Retinal blood flow response to posture change in glaucoma patients compared with healthy subjects. Ophthalmology 115, 246-252. doi: 10.1016/j.ophtha.2007.04.055

Fernandez-Durango, R., Fernandez-Martinez, A., Garcia-Feijoo, J., Castillo, A., De La Casa, J. M., Garcia-Bueno, B., et al. (2008). Expression of nitrotyrosine and oxidative consequences in the trabecular meshwork of patients with primary open-angle glaucoma. Invest. Ophthalmol. Vis. Sci. 49, 2506-2511. doi: 10.1167/iovs.07-1363

Fernandez-Durango, R., Moya, F. J., Ripodas, A., De Juan, J. A., Fernandez-Cruz, A., and Bernal, R. (1999). Type B and type C natriuretic peptide receptors modulate intraocular pressure in the rabbit eye. Eur. J. Pharmacol. 364, 107-113. doi: 10.1016/S0014-2999(98)00828-0

Fernandez-Durango, R., Nunez, D. J., and Brown, M. J. (1995). Messenger RNAs encoding the natriuretic peptides and their receptors are expressed in the eye. Exp. Eye Res. 61, 723-729. doi: 10.1016/S0014-4835(05)80023-5

Flammer, J., Orgul, S., Costa, V. P., Orzalesi, N., Krieglstein, G. K., Serra, L. M., et al. (2002). The impact of ocular blood flow in glaucoma. Prog. Retin. Eye Res. 21, 359-393. doi: 10.1016/S1350-9462(02)00008-3

Flugel, C., Barany, E. H., and Lutjen-Drecoll, E. (1990). Histochemical differences within the ciliary muscle and its function in accommodation. Exp. Eye Res. 50, 219-226. doi: 10.1016/0014-4835(90)90234-L

Foresta, C., Caretta, N., Zuccarello, D., Poletti, A., Biagioli, A., Caretti, L., et al. (2008). Expression of the PDE5 enzyme on human retinal tissue: new aspects of PDE5 inhibitors ocular side effects. Eye 22, 144-149. doi: 10.1038/sj.eye.6702908

Francis, S. H., Blount, M. A., and Corbin, J. D. (2011). Mammalian cyclic nucleotide phosphodiesterases: molecular mechanisms and physiological functions. Physiol. Rev. 91, 651-690. doi: 10.1152/physrev.00030.2010

Franco-Bourland, R. E., Guizar-Sahagun, G., Garcia, G. A., Odor-Morales, A., Alvarez, A., Esquivel, F., et al. (1998). Retinal vulnerability to glutamate excitotoxicity in canine glaucoma: induction of neuronal nitric oxide synthase in retinal ganglion cells. Proc. West. Pharmacol. Soc. 41, 201-204.

Friebe, A., Mergia, E., Dangel, O., Lange, A., and Koesling, D. (2007). Fatal gastrointestinal obstruction and hypertension in mice lacking nitric oxidesensitive guanylyl cyclase. Proc. Natl. Acad. Sci. U.S.A. 104, 7699-7704. doi: 10.1073/pnas.0609778104

Fujiwara, N., Matsuo, T., and Ohtsuki, H. (2003). Protein expression, genomic structure, and polymorphisms of oculomedin. Ophthal. Genet. 24, 141-151. doi: 10.1076/opge.24.3.141.15604

Galassi, F., Renieri, G., Sodi, A., Ucci, F., Vannozzi, L., and Masini, E. (2004). Nitric oxide proxies and ocular perfusion pressure in primary open angle glaucoma. Br. J. Ophthalmol. 88, 757-760. doi: 10.1136/bjo.2003.028357

Galassi, F., Sodi, A., Ucci, F., Renieri, G., Pieri, B., and Masini, E. (2000). Ocular haemodynamics and nitric oxide in normal pressure glaucoma. Acta. Ophthalmol. Scand. Suppl. 78, 37-38. doi: 10.1111/j.1600-0420.2000.tb01093.x
Garcia Filho, C. A., Prata, T. S., Sousa, A. K., Doi, L. M., and Melo, L. A. Jr. (2011). Intraocular pressure, corneal thickness, and corneal hysteresis in Steinert's myotonic dystrophy. Arq. Bras. Oftalmol. 74, 161-162. doi: 10.1590/S000427492011000300002

Gasser, P., and Flammer, J. (1991). Blood-cell velocity in the nailfold capillaries of patients with normal-tension and high-tension glaucoma. Am. J. Ophthalmol. $111,585-588$.

Ghofrani, H. A., Galie, N., Grimminger, F., Grunig, E., Humbert, M., Jing, Z. C., et al. (2013). Riociguat for the treatment of pulmonary arterial hypertension. New Engl. J. Med. 369, 330-340. doi: 10.1056/NEJMoa1209655

Giuffrida, S., Bucolo, C., and Drago, F. (2003). Topical application of a nitric oxide synthase inhibitor reduces intraocular pressure in rabbits with experimental glaucoma. J. Ocul. Pharmacol. Ther. 19, 527-534. doi: $10.1089 / 108076803322660440$

Grunwald, J. E., Jacob, S. S., Siu, K., Piltz, J., and Dupont, J. (2001). Acute effects of sldenafil ctrate (Viagra) on intraocular pressure in open-angle glaucoma. Am. J. Ophthalmol. 132, 872-874. doi: 10.1016/S0002-9394(01)01268-5

Haberecht, M. F., Schmidt, H. H., Mills, S. L., Massey, S. C., Nakane, M., and Redburn-Johnson, D. A. (1998). Localization of nitric oxide synthase, NADPH diaphorase and soluble guanylyl cyclase in adult rabbit retina. Vis. Neurosci. 15, 881-890. doi: 10.1017/S0952523898155104

Harris, A., Rechtman, E., Siesky, B., Jonescu-Cuypers, C., Mccranor, L., and Garzozi, H. J. (2005). The role of optic nerve blood flow in the pathogenesis of glaucoma. Ophthalmol. Clin. North Am. 18, 345-353. doi: 10.1016/j.ohc.2005.04.001

Hashizume, K., Mashima, Y., Fumayama, T., Ohtake, Y., Kimura, I., Yoshida, K., et al. (2005). Genetic polymorphisms in the angiotensin II receptor gene and their association with open-angle glaucoma in a Japanese population. Invest. Ophthalmol. Vis. Sci. 46, 1993-2001. doi: 10.1167/iovs.04-1100

He, Z., Vingrys, A. J., Armitage, J. A., and Bui, B. V. (2011). The role of blood pressure in glaucoma. Clin. Exp. Optom. 94, 133-149. doi: 10.1111/j.14440938.2010.00564.x

Heijl, A., Leske, M. C., Bengtsson, B., Hyman, L., Bengtsson, B., and Hussein, M. (2002). Reduction of intraocular pressure and glaucoma progression: results from the Early Manifest Glaucoma Trial. Arch. Ophthalmol. 120, 1268-1279. doi: 10.1001/archopht.120.10.1268

Henry, E., Newby, D. E., Webb, D. J., and O’brien, C. (1999). Peripheral endothelial dysfunction in normal pressure glaucoma. Invest. Ophthalmol. Vis. Sci. 40, 1710-1714.

Hobbs, A. J. (1997). Soluble guanylate cyclase: the forgotten sibling. Trends Pharmacol. Sci. 18, 484-491. doi: 10.1016/S0165-6147(97)01137-1

Honjo, M., Tanihara, H., Inatani, M., Kido, N., Sawamura, T., Yue, B. Y., et al. (2001). Effects of rho-associated protein kinase inhibitor Y-27632 on intraocular pressure and outflow facility. Invest. Ophthalmol. Vis. Sci. 42, 137-144.

Hulsman, C. A., Vingerling, J. R., Hofman, A., Witteman, J. C., and De Jong, P. T. (2007). Blood pressure, arterial stiffness, and open-angle glaucoma: the Rotterdam study. Arch. Ophthalmol. 125, 805-812. doi: 10.1001/archopht.125.6.805

Ishikawa, K., Funayama, T., Ohtake, Y., Kimura, I., Ideta, H., Nakamoto, K., et al. (2005). Association between glaucoma and gene polymorphism of endothelin type A receptor. Mol. Vis. 11, 431-437.

Jaffrey, S. R., Erdjument-Bromage, H., Ferris, C. D., Tempst, P., and Snyder, S. H. (2001). Protein S-nitrosylation: a physiological signal for neuronal nitric oxide. Nat. Cell Biol. 3, 193-197. doi: 10.1038/35055104

Javadiyan, S., Burdon, K. P., Whiting, M. J., Abhary, S., Straga, T., Hewitt, A. W., et al. (2012). Elevation of serum asymmetrical and symmetrical dimethylarginine in patients with advanced glaucoma. Invest. Ophthalmol. Vis. Sci. 53, 1923-1927. doi: 10.1167/iovs.11-8420

John, S. W., Smith, R. S., Savinova, O. V., Hawes, N. L., Chang, B., Turnbull, D., et al. (1998). Essential iris atrophy, pigment dispersion, and glaucoma in DBA/2J mice. Invest. Ophthalmol. Vis. Sci. 39, 951-962.

Junemann, A. G., Von Ahsen, N., Reulbach, U., Roedl, J., Bonsch, D., Kornhuber, J., et al. (2005). C677T variant in the methylentetrahydrofolate reductase gene is a genetic risk factor for primary open-angle glaucoma. Am. J. Ophthalmol. 139, 721-723. doi: 10.1016/j.ajo.2004.09.081

Juronen, E., Tasa, G., Veromann, S., Parts, L., Tiidla, A., Pulges, R., et al. (2000). Polymorphic glutathione S-transferase M1 is a risk factor of primary open-angle glaucoma among Estonians. Exp. Eye Res. 71, 447-452. doi: 10.1006/exer.2000.0899 
Kaiser, H. J., and Flammer, J. (1991). Systemic hypotension: a risk factor for glaucomatous damage? Ophthalmologica 203, 105-108.

Kajimura, M., Shimoyama, M., Tsuyama, S., Suzuki, T., Kozaki, S., Takenaka, S., et al. (2003). Visualization of gaseous monoxide reception by soluble guanylate cyclase in the rat retina. FASEB J. 17, 506-508. doi: 10.1096/fj.02-0359fje

Kamikawatoko, S., Tokoro, T., Ishida, A., Masuda, H., Hamasaki, H., Sato, J., et al. (1998). Nitric oxide relaxes bovine ciliary muscle contracted by carbachol through elevation of cyclic GMP. Exp. Eye Res. 66, 1-7. doi: 10.1006/exer.1997.0408

Kang, J. H., Wiggs, J. L., Rosner, B. A., Haines, J., Abdrabou, W., and Pasquale, L. R. (2011). Endothelial nitric oxide synthase gene variants and primary openangle glaucoma: interactions with hypertension, alcohol intake, and cigarette smoking. Arch. Ophthalmol. 129, 773-780. doi: 10.1001/archophthalmol. 2011.118

Kang, J. H., Wiggs, J. L., Rosner, B. A., Hankinson, S. E., Abdrabou, W., Fan, B. J., et al. (2010). Endothelial nitric oxide synthase gene variants and primary openangle glaucoma: interactions with sex and postmenopausal hormone use. Invest. Ophthalmol. Vis. Sci. 51, 971-979. doi: 10.1167/iovs.09-4266

Kass, M. A., Gordon, M. O., Gao, F., Heuer, D. K., Higginbotham, E. J., Johnson, C. A., et al. (2010). Delaying treatment of ocular hypertension: the ocular hypertension treatment study. Arch. Ophthalmol. 128, 276-287. doi: 10.1001/archophthalmol.2010.20

Kass, M. A., Heuer, D. K., Higginbotham, E. J., Johnson, C. A., Keltner, J. L., Miller, J. P., et al. (2002). The ocular hypertension treatment study: a randomized trial determines that topical ocular hypotensive medication delays or prevents the onset of primary open-angle glaucoma. Arch. Ophthalmol. 120, 701-713; discussion 829-730. doi: 10.1001/archopht.120.6.701

Kaufman, P. L. (2008). Enhancing trabecular outflow by disrupting the actin cytoskeleton, increasing uveoscleral outflow with prostaglandins, and understanding the pathophysiology of presbyopia interrogating Mother Nature: asking why, asking how, recognizing the signs, following the trail. Exp. Eye Res. 86, 3-17. doi: 10.1016/j.exer.2007.10.007

Kee, C., Kaufman, P. L., and Gabelt, B. T. (1994). Effect of 8-Br cGMP on aqueous humor dynamics in monkeys. Invest. Ophthalmol. Vis. Sci. 35, 2769-2773.

Khoobehi, B., Chiroli, V., Ronchetti, D., Miglietta, D., Thompson, H., Ongini, E., et al. (2011). Enhanced oxygen saturation in optic nerve head of non-human primate eyes following the intravitreal injection of NCX 434, an innovative nitric oxide-donating glucocorticoid. J. Ocul. Pharmacol. Ther. 27, 115-121. doi: 10.1089/jop.2010.0150

Klein, B. E., Klein, R., and Knudtson, M. D. (2005). Intraocular pressure and systemic blood pressure: longitudinal perspective: the Beaver Dam Eye Study. Br. J. Ophthalmol. 89, 284-287. doi: 10.1136/bjo.2004.048710

Klein, B. E., Klein, R., and Linton, K. L. (1992). Intraocular pressure in an American community. the beaver dam eye study. Invest. Ophthalmol. Vis. Sci. 33, 2224-2228.

Koksal, M., Ozdemir, H., Kargi, S., Yesilli, C., Tomac, S., Mahmutyazicioglu, K., et al. (2005). The effects of sildenafil on ocular blood flow. Acta. Ophthalmol. Scand. 83, 355-359. doi: 10.1111/j.1600-0420.2005.00422.x

Konstas, A. G., Quaranta, L., Mikropoulos, D. G., Nasr, M. B., Russo, A., Jaffee, H. A., et al. (2012). Peak intraocular pressure and glaucomatous progression in primary open-angle glaucoma. J. Ocul. Pharmacol. Ther. 28, 26-32. doi: 10.1089/jop.2011.0081

Korenfeld, M. S., and Becker, B. (1989). Atrial natriuretic peptides. Effects on intraocular pressure, cGMP, and aqueous flow. Invest. Ophthalmol. Vis. Sci. 30, 2385-2392.

Kotikoski, H., Alajuuma, P., Moilanen, E., Salmenpera, P., Oksala, O., Laippala, P., et al. (2002). Comparison of nitric oxide donors in lowering intraocular pressure in rabbits: role of cyclic GMP. J. Ocul. Pharmacol. Ther. 18, 11-23. doi: 10.1089/108076802317233171

Kotikoski, H., Vapaatalo, H., and Oksala, O. (2003). Nitric oxide and cyclic GMP enhance aqueous humor outflow facility in rabbits. Curr. Eye Res. 26, 119-123. doi: 10.1076/ceyr.26.2.119.14511

Krauss, A. H., Impagnatiello, F., Toris, C. B., Gale, D. C., Prasanna, G., Borghi, V., et al. (2011). Ocular hypotensive activity of BOL-303259-X, a nitric oxide donating prostaglandin F2alpha agonist, in preclinical models. Exp. Eye Res. 93, 250-255. doi: 10.1016/j.exer.2011.03.001

Krupin, T., Liebmann, J. M., Greenfield, D. S., Ritch, R., and Gardiner, S. (2011). A randomized trial of brimonidine versus timolol in preserving visual function: results from the Low-Pressure Glaucoma Treatment Study. Am. J. Ophthalmol. 151, 671-681. doi: 10.1016/j.ajo.2010.09.026

Lee, J. Y., Yoo, C., Jung, J. H., Hwang, Y. H., and Kim, Y. Y. (2012). The effect of lateral decubitus position on intraocular pressure in healthy young subjects. Acta. Ophthalmol. 90, e68-e72. doi: 10.1111/j.1755-3768.2011.02208.x

Lee, J. Y., Yoo, C., and Kim, Y. Y. (2013). The effect of lateral decubitus position on intraocular pressure in patients with untreated open-angle glaucoma. Am. J. Ophthalmol. 155, 329-335.e322. doi: 10.1016/j.ajo.2012.08.003

Leske, M. C. (2009). Ocular perfusion pressure and glaucoma: clinical trial and epidemiologic findings. Curr. Opin. Ophthalmol. 20, 73-78. doi: 10.1097/ICU.0b013e32831eef82

Leske, M. C., Connell, A. M., Wu, S. Y., Nemesure, B., Li, X., Schachat, A., et al. (2001). Incidence of open-angle glaucoma: the Barbados eye studies. the Barbados eye studies group. Arch. Ophthalmol. 119, 89-95.

Leske, M. C., Heijl, A., Hussein, M., Bengtsson, B., Hyman, L., and Komaroff, E. (2003). Factors for glaucoma progression and the effect of treatment: the early manifest glaucoma trial. Arch. Ophthalmol. 121, 48-56. doi: 10.1001/archopht.121.1.48

Leske, M. C., Heijl, A., Hyman, L., Bengtsson, B., Dong, L., and Yang, Z. (2007). Predictors of long-term progression in the early manifest glaucoma trial. Ophthalmology 114, 1965-1972. doi: 10.1016/j.ophtha.2007.03.016

Leske, M. C., Wu, S. Y., Hennis, A., Honkanen, R., and Nemesure, B. (2008). Risk factors for incident open-angle glaucoma: the Barbados Eye Studies. Ophthalmology 115, 85-93. doi: 10.1016/j.ophtha.2007.03.017

Liao, S., Cheng, G., Conner, D. A., Huang, Y., Kucherlapati, R. S., Munn, L. L., et al. (2011). Impaired lymphatic contraction associated with immunosuppression. Proc. Natl. Acad. Sci. U.S.A. 108, 18784-18789. doi: 10.1073/pnas.1116 152108

Lin, H. J., Chen, W. C., Tsai, F. J., and Tsai, S. W. (2002). Distributions of p53 codon 72 polymorphism in primary open angle glaucoma. $\mathrm{Br}$. J. Ophthalmol. 86, 767-770. doi: 10.1136/bjo.86.7.767

Lin, H. J., Tsai, C. H., Tsai, F. J., Chen, W. C., Chen, H. Y., and Fan, S. S. (2004). Transporter associated with antigen processing gene 1 codon 333 and codon 637 polymorphisms are associated with primary open-angle glaucoma. Mol. Diagn. 8, 245-252. doi: 10.1007/BF03260069

Lin, H. J., Tsai, F. J., Chen, W. C., Shi, Y. R., Hsu, Y., and Tsai, S. W. (2003a). Association of tumour necrosis factor alpha -308 gene polymorphism with primary open-angle glaucoma in Chinese. Eye 17, 31-34. doi: 10.1038/sj.eye.6700227

Lin, H. J., Tsai, S. C., Tsai, F. J., Chen, W. C., Tsai, J. J., and Hsu, C. D. (2003b). Association of interleukin lbeta and receptor antagonist gene polymorphisms with primary open-angle glaucoma. Ophthalmologica 217, 358-364. doi: $10.1159 / 000071352$

Liu, B., and Neufeld, A. H. (2001). Nitric oxide synthase-2 in human optic nerve head astrocytes induced by elevated pressure in vitro. Arch. Ophthalmol. 119, 240-245.

Lorget, F., Kaci, N., Peng, J., Benoist-Lasselin, C., Mugniery, E., Oppeneer, T., et al. (2012). Evaluation of the therapeutic potential of a CNP analog in a Fgfr3 mouse model recapitulating achondroplasia. Am. J. Hum. Genet. 91, 1108-1114. doi: 10.1016/j.ajhg.2012.10.014

Lu, Z., Overby, D. R., Scott, P. A., Freddo, T. F., and Gong, H. (2008). The mechanism of increasing outflow facility by rho-kinase inhibition with Y-27632 in bovine eyes. Exp. Eye Res. 86, 271-281. doi: 10.1016/j.exer.2007.10.018

Magalhaes Da Silva, T., Rocha, A. V., Lacchini, R., Marques, C. R., Silva, E. S., Tanus-Santos, J. E., et al. (2012). Association of polymorphisms of endothelial nitric oxide synthase (eNOS) gene with the risk of primary open angle glaucoma in a Brazilian population. Gene 502, 142-146. doi: 10.1016/j.gene.2012. 04.047

Majsterek, I., Malinowska, K., Stanczyk, M., Kowalski, M., Blaszczyk, J., Kurowska, A. K., et al. (2011a). Evaluation of oxidative stress markers in pathogenesis of primary open-angle glaucoma. Exp. Mol. Pathol. 90, 231-237. doi: 10.1016/j.yexmp.2011.01.001

Majsterek, I., Markiewicz, L., Przybylowska, K., Gacek, M., Kurowska, A. K., Kaminska, A., et al. (2011b). Association of MMP1-1607 1G/2G and TIMP1 372 $\mathrm{T} / \mathrm{C}$ gene polymorphisms with risk of primary open angle glaucoma in a Polish population. Med. Sci. Monit. 17, CR417-421. doi: 10.12659/MSM.881854

Marro, M. L., Peiro, C., Panayiotou, C. M., Baliga, R. S., Meurer, S., Schmidt, H. H., et al. (2008). Characterization of the human alphal betal soluble guanylyl cyclase promoter: key role for NF-kappaB(p50) and CCAAT-binding 
factors in regulating expression of the nitric oxide receptor. J. Biol. Chem. 283, 20027-20036. doi: 10.1074/jbc.M801223200

Masuda, H., Tamaoki, S., Goto, M., Ishida, A., Kamikawatoko, S., Tokoro, T., et al. (1997). Nitric oxide-induced ciliary muscle relaxation during contraction with endothelin-1 is mediated through elevation of cyclic GMP. Curr. Eye Res. 16, 1245-1251. doi: 10.1076/ceyr.16.12.1245.5025

May, C. A., and Mittag, T. (2004). Neuronal nitric oxide synthase (nNOS) positive retinal amacrine cells are altered in the DBA/2NNia mouse, a murine model for angle-closure glaucoma. J. Glaucoma 13, 496-499. doi: 10.1097/01.ijg.0000137435.83307.fd

Mckie, P. M., Sangaralingham, S. J., and Burnett, J. C., Jr. (2010). CD-NP: an innovative designer natriuretic peptide activator of particulate guanylyl cyclase receptors for cardiorenal disease. Curr. Heart Fail. Rep. 7, 93-99. doi: 10.1007/s11897-010-0016-6

Meguro, A., Inoko, H., Ota, M., Mizuki, N., and Bahram, S. (2010). Genome-wide association study of normal tension glaucoma: common variants in SRBD1 and ELOVL5 contribute to disease susceptibility. Ophthalmology 117, 1331-1338. e1335. doi: 10.1016/j.ophtha.2009.12.001

Memarzadeh, F., Ying-Lai, M., Chung, J., Azen, S. P., and Varma, R. (2010). Blood pressure, perfusion pressure, and open-angle glaucoma: the Los Angeles Latino Eye Study. Invest. Ophthalmol. Vis. Sci. 51, 2872-2877. doi: 10.1167/iovs.08-2956

Mendelsohn, M. E. (2005). In hypertension, the kidney is not always the heart of the matter. J. Clin. Invest. 115, 840-844. doi: 10.1172/JCI200524806

Mergia, E., Friebe, A., Dangel, O., Russwurm, M., and Koesling, D. (2006). Spare guanylyl cyclase NO receptors ensure high NO sensitivity in the vascular system. J. Clin. Invest. 116, 1731-1737. doi: 10.1172/JCI27657

Mergia, E., Russwurm, M., Zoidl, G., and Koesling, D. (2003). Major occurrence of the new alpha(2)beta(1) isoform of NO-sensitive guanylyl cyclase in brain. Cell. Signall. 15, 189-195. doi: 10.1016/S0898-6568(02)00078-5

Michael, S. K., Surks, H. K., Wang, Y., Zhu, Y., Blanton, R., Jamnongjit, M., et al. (2008). High blood pressure arising from a defect in vascular function. Proc. Natl. Acad. Sci. U.S.A. 105, 6702-6707. doi: 10.1073/pnas.0802128105

Mineo, C., and Shaul, P. W. (2012). Regulation of eNOS in caveolae. Adv. Exp. Med. Biol. 729, 51-62. doi: 10.1007/978-1-4614-1222-9_4

Mittag, T. W., Tormay, A., Ortega, M., and Severin, C. (1987). Atrial natriuretic peptide (ANP), guanylate cyclase, and intraocular pressure in the rabbit eye. Curr. Eye Res. 6, 1189-1196. doi: 10.3109/02713688709025228

Moncada, S., and Higgs, A. (1993). The L-arginine-nitric oxide pathway. New Engl. J. Med. 329, 2002-2012. doi: 10.1056/NEJM199312303292706

Monemi, S., Spaeth, G., Dasilva, A., Popinchalk, S., Ilitchev, E., Liebmann, J., et al. (2005). Identification of a novel adult-onset primary open-angle glaucoma (POAG) gene on 5q22.1. Hum. Mol. Genet. 14, 725-733. doi: 10.1093/hmg/ddi068

Moore, D., Harris, A., Wudunn, D., Kheradiya, N., and Siesky, B. (2008). Dysfunctional regulation of ocular blood flow: a risk factor for glaucoma? Clin. Ophthalmol. 2, 849-861.

Morgan, J., Caprioli, J., and Koseki, Y. (1999). Nitric oxide mediates excitotoxic and anoxic damage in rat retinal ganglion cells cocultured with astroglia. Arch. Ophthalmol. 117, 1524-1529. doi: 10.1001/archopht.117.11.1524

Mukesh, B. N., Mccarty, C. A., Rait, J. L., and Taylor, H. R. (2002). Five-year incidence of open-angle glaucoma: the visual impairment project. Ophthalmology 109, 1047-1051. doi: 10.1016/S0161-6420(02)01040-0

Munzel, T., Gori, T., Bruno, R. M., and Taddei, S. (2010). Is oxidative stress a therapeutic target in cardiovascular disease? Eur. Heart J. 31, 2741-2748. doi: 10.1093/eurheartj/ehq396

Nakano, M., Ikeda, Y., Tokuda, Y., Fuwa, M., Omi, N., Ueno, M., et al. (2012). Common variants in CDKN2B-AS1 associated with optic-nerve vulnerability of glaucoma identified by genome-wide association studies in Japanese. PLoS ONE 7:e33389. doi: 10.1371/journal.pone.0033389

Nathanson, J. A. (1988). Direct application of a guanylate cyclase activator lowers intraocular pressure. Eur. J. Pharmacol. 147, 155-156. doi: 10.1016/00142999(88)90648-6

Nathanson, J. A. (1992). Nitrovasodilators as a new class of ocular hypotensive agents. J. Pharmacol. Exp. Ther. 260, 956-965.

Nathanson, J. A., and Mckee, M. (1995a). Alterations of ocular nitric oxide synthase in human glaucoma. Invest. Ophthalmol. Vis. Sci. 36, 1774-1784.

Nathanson, J. A., and Mckee, M. (1995b). Identification of an extensive system of nitric oxide-producing cells in the ciliary muscle and outflow pathway of the human eye. Invest. Ophthalmol. Vis. Sci. 36, 1765-1773.
Neufeld, A. H., Das, S., Vora, S., Gachie, E., Kawai, S., Manning, P. T., et al. (2002). A prodrug of a selective inhibitor of inducible nitric oxide synthase is neuroprotective in the rat model of glaucoma. J. Glaucoma 11, 221-225. doi: 10.1097/00061198-200206000-00010

Neufeld, A. H., Hernandez, M. R., and Gonzalez, M. (1997). Nitric oxide synthase in the human glaucomatous optic nerve head. Arch. Ophthalmol. 115, 497-503. doi: 10.1001/archopht.1997.01100150499009

Neufeld, A. H., Sawada, A., and Becker, B. (1999). Inhibition of nitric-oxide synthase 2 by aminoguanidine provides neuroprotection of retinal ganglion cells in a rat model of chronic glaucoma. Proc. Natl. Acad. Sci. U.S.A. 96, 9944-9948. doi: 10.1073/pnas.96.17.9944

Nimmegeers, S., Sips, P., Buys, E., Brouckaert, P., and Van De Voorde, J. (2007). Functional role of the soluble guanylyl cyclase alpha(1) subunit in vascular smooth muscle relaxation. Cardiovasc. Res. 76, 149-159. doi: 10.1016/j.cardiores.2007.06.002

Nouri-Mahdavi, K., Hoffman, D., Coleman, A. L., Liu, G., Li, G., Gaasterland, D., et al. (2004). Predictive factors for glaucomatous visual field progression in the advanced Glaucoma intervention study. Ophthalmology 111, 1627-1635. doi: 10.1016/j.ophtha.2004.02.017

Oh, S. W., Lee, S., Park, C., and Kim, D. J. (2005). Elevated intraocular pressure is associated with insulin resistance and metabolic syndrome. Diabetes Metab. Res. Rev. 21, 434-440. doi: 10.1002/dmrr.529

Ozel, A. B., Moroi, S. E., Reed, D. M., Nika, M., Schmidt, C. M., Akbari, S., et al. (2014). Genome-wide association study and meta-analysis of intraocular pressure. Hum. Genet. 133, 41-57. doi: 10.1007/s00439-013-1349-5

Park, H. Y., Jung, K. I., Na, K. S., Park, S. H., and Park, C. K. (2012). Visual field characteristics in normal-tension glaucoma patients with autonomic dysfunction and abnormal peripheral microcirculation. Am. J. Ophthalmol. 154, 466-475 e461. doi: 10.1016/j.ajo.2012.03.028

Park, S. C., De Moraes, C. G., Teng, C. C., Tello, C., Liebmann, J. M., and Ritch, R. (2011). Initial parafoveal versus peripheral scotomas in glaucoma: risk factors and visual field characteristics. Ophthalmology 118, 1782-1789. doi: 10.1016/j.ophtha.2011.02.013

Park, S. H., Kim, J. H., Kim, Y. H., and Park, C. K. (2007). Expression of neuronal nitric oxide synthase in the retina of a rat model of chronic glaucoma. Vis. Res. 47, 2732-2740. doi: 10.1016/j.visres.2007.07.011

Pasquale, L. R., and Kang, J. H. (2011). Female reproductive factors and primary open-angle glaucoma in the nurses' health study. Eye 25, 633-641. doi: 10.1038/eye.2011.34

Pasutto, F., Keller, K. E., Weisschuh, N., Sticht, H., Samples, J. R., Yang, Y. F., et al. (2012). Variants in ASB10 are associated with open-angle glaucoma. Hum. Mol. Genet. 21, 1336-1349. doi: 10.1093/hmg/ddr572

Piggott, L. A., Hassell, K. A., Berkova, Z., Morris, A. P., Silberbach, M., and Rich, T. C. (2006). Natriuretic peptides and nitric oxide stimulate cGMP synthesis in different cellular compartments. J. Gen. Physiol. 128, 3-14. doi: 10.1085/jgp.200509403

Potter, L. R. (2011a). Guanylyl cyclase structure, function and regulation. Cell. Signal. 23, 1921-1926. doi: 10.1016/j.cellsig.2011.09.001

Potter, L. R. (2011b). Natriuretic peptide metabolism, clearance and degradation. FEBS J. 278, 1808-1817. doi: 10.1111/j.1742-4658.2011.08082.x

Potter, L. R. (2011c). Regulation and therapeutic targeting of peptideactivated receptor guanylyl cyclases. Pharmacol. Ther. 130, 71-82. doi: 10.1016/j.pharmthera.2010.12.005

Potter, L. R., Yoder, A. R., Flora, D. R., Antos, L. K., and Dickey, D. M. (2009). Natriuretic peptides: their structures, receptors, physiologic functions and therapeutic applications. Handb. Exp. Pharmacol. 341-366. doi: 10.1007/9783-540-68964-5_15

Quigley, H. A. (2011). Glaucoma. Lancet 377, 1367-1377. doi: 10.1016/S01406736(10)61423-7

Ramdas, W. D., Van Koolwijk, L. M., Lemij, H. G., Pasutto, F., Cree, A. J., Thorleifsson, G., et al. (2011). Common genetic variants associated with open-angle glaucoma. Hum. Mol. Genet. 20, 2464-2471. doi: 10.1093/hmg/ ddr 120

Rao, V. P., and Epstein, D. L. (2007). Rho GTPase/Rho kinase inhibition as a novel target for the treatment of glaucoma. BioDrugs 21, 167-177. doi: 10.2165/00063030-200721030-00004

Rezaie, T., Child, A., Hitchings, R., Brice, G., Miller, L., Coca-Prados, M., et al. (2002). Adult-onset primary open-angle glaucoma caused by mutations in optineurin. Science 295, 1077-1079. doi: 10.1126/science.1066901 
Rollin, R., Mediero, A., Roldan-Pallares, M., Fernandez-Cruz, A., and FernandezDurango, R. (2004). Natriuretic peptide system in the human retina. Mol. Vis. $10,15-22$.

Rudnicka, A. R., Mt-Isa, S., Owen, C. G., Cook, D. G., and Ashby, D. (2006). Variations in primary open-angle glaucoma prevalence by age, gender, and race: a Bayesian meta-analysis. Invest. Ophthalmol. Vis. Sci. 47, 4254-4261. doi: 10.1167/iovs.06-0299

Russ, P. K., Kupperman, A. I., Presley, S. H., Haselton, F. R., and Chang, M. S. (2010). Inhibition of RhoA signaling with increased Bves in trabecular meshwork cells. Invest. Ophthalmol. Vis. Sci. 51, 223-230. doi: 10.1167/iovs. 09-3539

Russwurm, M., Behrends, S., Harteneck, C., and Koesling, D. (1998). Functional properties of a naturally occurring isoform of soluble guanylyl cyclase. Biochem. J. 335, 125-130.

Sacca, S. C., Rolando, M., Marletta, A., Macri, A., Cerqueti, P., and Ciurlo, G. (1998). Fluctuations of intraocular pressure during the day in open-angle glaucoma, normal-tension glaucoma and normal subjects. Ophthalmologica 212, 115-119. doi: 10.1159/000027290

Saleh, M., Nagaraju, M., and Porciatti, V. (2007). Longitudinal evaluation of retinal ganglion cell function and IOP in the DBA/2J mouse model of glaucoma. Invest. Ophthalmol. Vis. Sci. 48, 4564-4572. doi: 10.1167/iovs.07-0483

Sarfarazi, M., Child, A., Stoilova, D., Brice, G., Desai, T., Trifan, O. C., et al. (1998). Localization of the fourth locus (GLC1E) for adult-onset primary openangle glaucoma to the 10p15-p14 region. Am. J. Hum. Genet. 62, 641-652. doi: $10.1086 / 301767$

Sauzeau, V., Rolli-Derkinderen, M., Marionneau, C., Loirand, G., and Pacaud, P. (2003). RhoA expression is controlled by nitric oxide through cGMPdependent protein kinase activation. J. Biol. Chem. 278, 9472-9480. doi: 10.1074/jbc.M212776200

Scheetz, T. E., Fingert, J. H., Wang, K., Kuehn, M. H., Knudtson, K. L., Alward, W. L., et al. (2013). A genome-wide association study for primary open angle glaucoma and macular degeneration reveals novel Loci. PLoS ONE 8:e58657. doi: 10.1371/journal.pone.0058657

Schmidl, D., Garhofer, G., and Schmetterer, L. (2011). The complex interaction between ocular perfusion pressure and ocular blood flow - relevance for glaucoma. Exp. Eye Res. 93, 141-155. doi: 10.1016/j.exer.2010.09.002

Schmidt, K. G., Geyer, O., and Mittag, T. W. (2004). Adenylyl and guanylyl cyclase activity in the choroid. Exp. Eye Res. 78, 901-907. doi: 10.1016/j.exer.2004.01.008

Schneemann, A., Dijkstra, B. G., Van Den Berg, T. J., Kamphuis, W., and Hoyng, P. F. (2002). Nitric oxide/guanylate cyclase pathways and flow in anterior segment perfusion. Graefe's Arch. Clin. Exp. Ophthalmol. 240, 936-941. doi: 10.1007/s00417-002-0559-7

Schuman, J. S., Erickson, K., and Nathanson, J. A. (1994). Nitrovasodilator effects on intraocular pressure and outflow facility in monkeys. Exp. Eye Res. 58, 99-105. doi: 10.1006/exer.1994.1199

Sharif, N. A., Williams, G. W., Crider, J. Y., Xu, S. X., and Davis, T. L. (2004). Molecular pharmacology of the DP/EP2 class prostaglandin AL-6598 and quantitative autoradiographic visualization of DP and EP2 receptor sites in human eyes. J. Ocul. Pharmacol. Ther. 20, 489-508. doi: 10.1089/jop.2004.20.489

Sheffield, V. C., Stone, E. M., Alward, W. L., Drack, A. V., Johnson, A. T., Streb, L. M., et al. (1993). Genetic linkage of familial open angle glaucoma to chromosome 1q21-q31. Nat. Genet. 4, 47-50. doi: 10.1038/ng0593-47

Shi, D., Funayama, T., Mashima, Y., Takano, Y., Shimizu, A., Yamamoto, K., et al. (2013). Association of HK2 and NCK2 with normal tension glaucoma in the Japanese population. PLoS ONE 8:e54115. doi: 10.1371/journal.pone.0054115

Smith, W. B., 2nd, Mccaslin, I. R., Gokce, A., Mandava, S. H., Trost, L., and Hellstrom, W. J. (2013). PDE5 inhibitors: considerations for preference and long-term adherence. Int. J. Clin. Pract. 67, 768-780. doi: 10.1111/ijcp.12074

Sommer, A., Tielsch, J. M., Katz, J., Quigley, H. A., Gottsch, J. D., Javitt, J., et al. (1991). Relationship between intraocular pressure and primary open angle glaucoma among white and black Americans. The Baltimore Eye Survey. Arch. Ophthalmol. 109, 1090-1095. doi: 10.1001/archopht.1991.01080080050026

Sponsel, W. E., Paris, G., Sandoval, S. S., Sanford, D. K., Harrison, J. M., Elliott, W. R., et al. (2000). Sildenafil and ocular perfusion. New Engl. J. Med. 342, 1680. doi: 10.1056/NEJM200006013422218

Stamer, W. D., Lei, Y., Boussommier-Calleja, A., Overby, D. R., and Ethier, C. R. (2011). eNOS, a pressure-dependent regulator of intraocular pressure. Invest. Ophthalmol. Vis. Sci. 52, 9438-9444. doi: 10.1167/iovs.11-7839
Stamler, J. S., Lamas, S., and Fang, F. C. (2001). Nitrosylation. the prototypic redox-based signaling mechanism. Cell 106, 675-683. doi: 10.1016/S00928674(01)00495-0

Stasch, J. P., Schmidt, P. M., Nedvetsky, P. I., Nedvetskaya, T. Y., HS, A. K., Meurer, S., et al. (2006). Targeting the heme-oxidized nitric oxide receptor for selective vasodilatation of diseased blood vessels. J. Clin. Invest. 116, 2552-2561. doi: 10.1172/JCI28371

Stoilova, D., Child, A., Trifan, O. C., Crick, R. P., Coakes, R. L., and Sarfarazi, M. (1996). Localization of a locus (GLC1B) for adult-onset primary open angle glaucoma to the 2cen-q13 region. Genomics 36, 142-150. doi: 10.1006/geno.1996.0434

Stone, E. M., Fingert, J. H., Alward, W. L., Nguyen, T. D., Polansky, J. R., Sunden, S. L., et al. (1997). Identification of a gene that causes primary open angle glaucoma. Science 275, 668-670. doi: 10.1126/science.275. []5300.668

Su, J., Scholz, P. M., and Weiss, H. R. (2005). Differential effects of cGMP produced by soluble and particulate guanylyl cyclase on mouse ventricular myocytes. Exp. Biol. Med. (Maywood) 230, 242-250.

Su, W. W., Cheng, S. T., Ho, W. J., Tsay, P. K., Wu, S. C., and Chang, S. H. (2008). Glaucoma is associated with peripheral vascular endothelial dysfunction. Ophthalmology 115, 1173-1178.e1171.

Sugrue, M. F., and Viader, M. P. (1986). Synthetic atrial natriuretic factor lowers rabbit intraocular pressure. Eur. J. Pharmacol. 130, 349-350. doi: 10.1016/00142999(86)90292-X

Surks, H. K., Mochizuki, N., Kasai, Y., Georgescu, S. P., Tang, K. M., Ito, M., et al. (1999). Regulation of myosin phosphatase by a specific interaction with cGMP- dependent protein kinase Ialpha. Science 286, 1583-1587. doi: $10.1126 /$ science. 286.5444 .1583

Takahata, K., Katsuki, H., Kume, T., Nakata, D., Ito, K., Muraoka, S., et al. (2003). Retinal neuronal death induced by intraocular administration of a nitric oxide donor and its rescue by neurotrophic factors in rats. Invest. Ophthalmol. Vis. Sci. 44, 1760-1766. doi: 10.1167/iovs.02-0471

Takashima, Y., Taniguchi, T., Yoshida, M., Haque, M. S., Igaki, T., Itoh, H., et al. (1998). Ocular hypotension induced by intravitreally injected C-type natriuretic peptide. Exp. Eye Res. 66, 89-96. doi: 10.1006/exer.1997.0403

Takimoto, E., Champion, H. C., Li, M., Ren, S., Rodriguez, E. R., Tavazzi, B., et al. (2005). Oxidant stress from nitric oxide synthase-3 uncoupling stimulates cardiac pathologic remodeling from chronic pressure load. J. Clin. Invest. 115, 1221-1231. doi: 10.1172/JCI21968

Tanihara, H., Inoue, T., Yamamoto, T., Kuwayama, Y., Abe, H., and Araie, M. (2013). Phase 2 randomized clinical study of a Rho kinase inhibitor, K-115, in primary open-angle glaucoma and ocular hypertension. Am. J. Ophthalmol. 156, 731-736. doi: 10.1016/j.ajo.2013.05.016

Thorleifsson, G., Magnusson, K. P., Sulem, P., Walters, G. B., Gudbjartsson, D. F., Stefansson, H., et al. (2007). Common sequence variants in the LOXL1 gene confer susceptibility to exfoliation glaucoma. Science 317, 1397-1400. doi: 10.1126/science. 1146554

Thorleifsson, G., Walters, G. B., Hewitt, A. W., Masson, G., Helgason, A., Dewan, A., et al. (2010). Common variants near CAV1 and CAV2 are associated with primary open-angle glaucoma. Nat. Genet. 42, 906-909. doi: 10.1038/ ng.661

Tielsch, J. M., Katz, J., Sommer, A., Quigley, H. A., and Javitt, J. C. (1995). Hypertension, perfusion pressure, and primary open-angle glaucoma. A population-based assessment. Arch. Ophthalmol. 113, 216-221. doi: 10.1001/archopht.1995.01100020100038

Torres, J., Darley-Usmar, V., and Wilson, M. T. (1995). Inhibition of cytochrome c oxidase in turnover by nitric oxide: mechanism and implications for control of respiration. Biochem. J. 312(Pt 1), 169-173.

Tsai, F. J., Lin, H. J., Chen, W. C., Chen, H. Y., and Fan, S. S. (2003). Insulin-like growth factor-II gene polymorphism is associated with primary open angle glaucoma. J. Clin. Lab. Anal. 17, 259-263. doi: 10.1002/jcla. 10106

Tsai, F. J., Lin, H. J., Chen, W. C., Tsai, C. H., and Tsai, S. W. (2004). A codon 31 ser-arg polymorphism of the WAF-1/CIP-1/p21/tumour suppressor gene in Chinese primary open-angle glaucoma. Acta. Ophthalmol. Scand. 82, 76-80. doi: 10.1111/j.1395-3907.2004.0180.x

Tsai, S., Bentley, E., Miller, P. E., Gomes, F. E., Vangyi, C., Wiese, A., et al. (2012). Gender differences in iridocorneal angle morphology: a potential explanation for the female predisposition to primary angle closure glaucoma in 
dogs. Vet. Ophthalmol. 15(Suppl. 1), 60-63. doi: 10.1111/j.1463-5224.2011. 00956.x

Tunny, T. J., Richardson, K. A., and Clark, C. V. (1998). Association study of the $5^{\prime}$ flanking regions of endothelial-nitric oxide synthase and endothelin-1 genes in familial primary open-angle glaucoma. Clin. Exp. Pharmacol. Physiol. 25, 26-29. doi: 10.1111/j.1440-1681.1998.tb02138.x

Tunny, T. J., Richardson, K. A., Clark, C. V., and Gordon, R. D. (1996). The atrial natriuretic peptide gene in patients with familial primary open-angle glaucoma. Biochem. Biophys. Res. Commun. 223, 221-225. doi: 10.1006/bbrc.1996.0874

Vajaranant, T. S., Nayak, S., Wilensky, J. T., and Joslin, C. E. (2010). Gender and glaucoma: what we know and what we need to know. Curr. Opin. Ophthalmol. 21, 91-99. doi: 10.1097/ICU.0b013e3283360b7e

Vajaranant, T. S., and Pasquale, L. R. (2012). Estrogen deficiency accelerates aging of the optic nerve. Menopause 19, 942-947. doi: 10.1097/gme.0b013e318 2443137

Van Koolwijk, L. M., Ramdas, W. D., Ikram, M. K., Jansonius, N. M., Pasutto, F., Hysi, P. G., et al. (2012). Common genetic determinants of intraocular pressure and primary open-angle glaucoma. PLoS Genet. 8:e1002611. doi: 10.1371/journal.pgen.1002611

Vanneste, G., Dhaese, I., Sips, P., Buys, E., Brouckaert, P., and Lefebvre, R. A. (2007) Gastric motility in soluble guanylate cyclase alpha 1 knock-out mice. J. Physiol. 584, 907-920. doi: 10.1113/jphysiol.2007.140608

Vermeersch, P., Buys, E., Pokreisz, P., Marsboom, G., Ichinose, F., Sips, P., et al. (2007). Soluble guanylate cyclase-alphal deficiency selectively inhibits the pulmonary vasodilator response to nitric oxide and increases the pulmonary vascular remodeling response to chronic hypoxia. Circulation 116, 936-943. doi: 10.1161/CIRCULATIONAHA.106.677245

Vincent, A. L., Billingsley, G., Buys, Y., Levin, A. V., Priston, M., Trope, G., et al. (2002). Digenic inheritance of early-onset glaucoma: CYP1B1, a potential modifier gene. Am. J. Hum. Genet. 70, 448-460. doi: 10.1086/338709

Vobig, M. A., Klotz, T., Staak, M., Bartz-Schmidt, K. U., Engelmann, U., and Walter, P. (1999). Retinal side-effects of sildenafil. Lancet 353, 375. doi: 10.1016/S01406736(98)05473-7

Vohra, R., Tsai, J. C., and Kolko, M. (2013). The role of inflammation in the pathogenesis of glaucoma. Surv. Ophthalmol. 58, 311-320. doi: 10.1016/j.survophthal.2012.08.010

Walkenbach, R. J., Ye, G. S., Korenfeld, M. S., and Boney, F. (1993). Atrial natriuretic peptide receptors on the corneal endothelium. Invest. Ophthalmol. Vis. Sci. 34, 2538-2543.

Weinreb, R. N., and Kaufman, P. L. (2009). The glaucoma research community and FDA look to the future: a report from the NEI/FDA CDER glaucoma clinical trial design and endpoints symposium. Invest. Ophthalmol. Vis. Sci. 50, 1497-1505. doi: 10.1167/iovs.08-2843

Weinreb, R. N., and Khaw, P. T. (2004). Primary open-angle glaucoma. Lancet 363, 1711-1720. doi: 10.1016/S0140-6736(04)16257-0

Wiederholt, M. (1998). Direct involvement of trabecular meshwork in the regulation of aqueous humor outflow. Curr. Opin. Ophthalmol. 9, 46-49. doi: 10.1097/00055735-199804000-00009
Wiederholt, M., Sturm, A., and Lepple-Wienhues, A. (1994). Relaxation of trabecular meshwork and ciliary muscle by release of nitric oxide. Invest. Ophthalmol. Vis. Sci. 35, 2515-2520.

Wiederholt, M., Thieme, H., and Stumpff, F. (2000). The regulation of trabecular meshwork and ciliary muscle contractility. Prog. Retin. Eye Res. 19, 271-295. doi: 10.1016/S1350-9462(99)00015-4

Wiggs, J. L., Kang, J. H., Yaspan, B. L., Mirel, D. B., Laurie, C., Crenshaw, A., et al. (2011). Common variants near CAV1 and CAV2 are associated with primary open-angle glaucoma in Caucasians from the USA. Hum. Mol. Genet. 20, 4707-4713. doi: 10.1093/hmg/ddr382

Wiggs, J. L., Yaspan, B. L., Hauser, M. A., Kang, J. H., Allingham, R. R., Olson, L. M., et al. (2012). Common variants at 9 p21 and $8 \mathrm{q} 22$ are associated with increased susceptibility to optic nerve degeneration in glaucoma. PLoS Genet. 8:e1002654. doi: 10.1371/journal.pgen.1002654

Wolfs, R. C., Klaver, C. C., Ramrattan, R. S., Van Duijn, C. M., Hofman, A., and De Jong, P. T. (1998). Genetic risk of primary open-angle glaucoma. Populationbased familial aggregation study. Arch. Ophthalmol. 116, 1640-1645. doi: 10.1001/archopht.116.12.1640

Wu, S. Y., and Leske, M. C. (1997). Associations with intraocular pressure in the Barbados Eye Study. Arch. Ophthalmol. 115, 1572-1576. doi: 10.1001/archopht.1997.01100160742012

Wu, S. Y., Nemesure, B., Hennis, A., and Leske, M. C. (2006). Nine-year changes in intraocular pressure: the Barbados Eye Studies. Arch. Ophthalmol. 124, 1631-1636. doi: 10.1001/archopht.124.11.1631

Yamamoto, R., Bredt, D. S., Snyder, S. H., and Stone, R. A. (1993). The localization of nitric oxide synthase in the rat eye and related cranial ganglia. Neuroscience 54, 189-200. doi: 10.1016/0306-4522(93)90393-T

Yucel, Y. H., Johnston, M. G., Ly, T., Patel, M., Drake, B., Gumus, E., et al. (2009). Identification of lymphatics in the ciliary body of the human eye: a novel "uveolymphatic" outflow pathway. Exp. Eye Res. 89, 810-819. doi: 10.1016/j.exer.2009.08.010

Conflict of Interest Statement: The authors declare that the research was conducted in the absence of any commercial or financial relationships that could be construed as a potential conflict of interest.

Received: 14 March 2014; paper pending published: 19 April 2014; accepted: 21 April 2014; published online: 19 May 2014.

Citation: Buys ES, Potter LR, Pasquale LR and Ksander BR (2014) Regulation of intraocular pressure by soluble and membrane guanylate cyclases and their role in glaucoma. Front. Mol. Neurosci. 7:38. doi: 10.3389/fnmol.2014.00038

This article was submitted to the journal Frontiers in Molecular Neuroscience.

Copyright (c) 2014 Buys, Potter, Pasquale and Ksander. This is an open-access article distributed under the terms of the Creative Commons Attribution License (CC BY). The use, distribution or reproduction in other forums is permitted, provided the original author(s) or licensor are credited and that the original publication in this journal is cited, in accordance with accepted academic practice. No use, distribution or reproduction is permitted which does not comply with these terms. 